\title{
Teaching Chemical Safety and Information Skills Using Risk Assessment
}

\author{
Samuella B. Sigmann ${ }^{1 *}$, Leah R. McEwen ${ }^{2}$ \\ ${ }^{1}$ A. R. Smith Department of Chemistry, Appalachian State University, Boone, \\ NC 28608 \\ ${ }^{2}$ Physical Sciences Library, Cornell University, Ithaca, NY 14853 \\ \{ HYPERLINK "mailto:*sigmannsb@appstate.edu" \}
}

There is an expectation from graduate schools, professional schools, industry, and K-12 administrators that students acquiring an undergraduate chemistry degree with laboratory research will gain the necessary knowledge and develop the required skills to successfully complete their specific laboratory projects and future jobs safely. This includes knowledgeable handling and management of biological, chemical, and physical laboratory hazards. To do this, students must be able to locate and evaluate chemical, regulatory, and toxicological information from various reliable sources. Traditionally, chemical safety and information literacy have been seen as skills to develop one project at a time rather than discrete chemistry sub-disciplines. However, many chemical educators, safety professionals, and librarians agree that these are more than project-specific skills. Chemical safety and information literacy are learning objectives in their own right. To support effective teaching of these objectives, best learning practices can be applied to the formal structure of "in lab" training and supported with safety and information literacy competencies. Educators should begin to consider developing innovative ways of incorporating the learning objectives and

\section{RESERVE THIS SPACE}


evaluation tools required to help students develop an aptitude for applying knowledge and skills in independent laboratory based work. Education organized around the aspects of knowledge and skill acquisition (accommodation, assimilation, and assessment) can help create a well-developed undergraduate curriculum promoting ethical, safe, and informed behaviors while increasing chemical safety knowledge that can be transferred from the teaching laboratory to the research laboratory.

\section{Introduction}

In the wake of several well publicized and tragic accidents which have occurred in university chemistry laboratories over the past few years, there has been much discussion among stakeholders (e.g., chemistry faculty, institutional administrators, professional organizations, and safety professionals) about how the "safety culture" in academic labs might be improved. ${ }^{1}$ Like most paradigm shifts, it should be expected that evolving our chemical safety culture from "reactive" to "proactive" (i.e., shifting the culture) in academic laboratories will take time. From the intensity of the current discussions, it might seem that the incorporation of chemical health and safety into the chemistry curriculum is a new idea. It is not.

...clearly the time has come when a basic competency in laboratory health and safety is required of all science and engineering graduates. The sooner this phase of education is included in earnest in chemistry courses and curricula, the sooner we will have fulfilled an ethical obligation. ${ }^{2}$

The above statement was published in a J. Chem. Ed. article in 1977, and yet most chemistry majors still graduate without a specific course in chemical safety on their transcript. This is not to imply that progress has not been made in the teaching of chemical safety, but moving forward from this point requires an evaluation of how future scientists and science teachers are educated in chemical safety within their discipline, especially with respect to hazard and risk management.

Ubiquitous to every wet laboratory is the need for information concerning chemical properties and research methodologies. Chemical information is highly valuable and sought after in chemical industry, medicine, materials, energy, and many other applied sciences. Numerous highly sophisticated and specialized collections of chemical literature and data have evolved to support these demands. However, important information for assessing and managing safety in 
labs is scattered across numerous sources and proactive searching for potential chemical incompatibility or process hazards poses a significant burden when planning experiments. Proficiency in searching diverse chemical literature has long been recognized as a core activity in the discipline, but as with chemical safety, there has not been widespread active incorporation of information literacy into the curriculum. ${ }^{3}$

Part of undergraduate education is preparing students for the workforce, ${ }^{4}$ but academia has tended to lag behind industry in promoting safe work environments, thus creating graduates without the needed safety and information skills. ${ }^{5}$ As Livingston noted in 1964, "Scientific research in the campus laboratories is one of the most exciting activities in the world of ideas, and one of the least orderly in the world of organizations." ${ }^{\circ}$ One recent analysis of OSHA injury and illness data showed that the incidence rates in academic institutions were significantly higher (2.2 per 100 workers $)$ when compared specifically to those of Dow Chemical (0.33 injuries per 100 workers). ${ }^{7}$ Educational programs that can produce chemistry graduates who have built a knowledge base in chemical safety and information literacy will be much more competitive in the job market.

\section{Teaching and Learning Chemical Safety and Information Management}

In 2015, the American Chemical Society Committee on Profession Training (ACS CPT) issued a revision of the ACS Guidelines and Evaluation Procedures for Bachelor's Degree Programs. In the revised edition, chemical safety and information management (along with several other core professional practices) are addressed under "Development of Student Skills." Skills represent the ability to apply knowledge, and thus knowledge of a topic is a prerequisite for skill development. Acquisition of knowledge should be embedded in the curriculum - preferably as a subject course that can treat the basic frameworks. Risk assessment is considered a full sub-discipline in the chemical safety industry. Building on the CPT guidelines, the education community needs to develop a framework for incorporating risk assessment into the undergraduate chemistry curriculum.

Chemical safety is more than memorizing safety rules that are offered at the beginning of the semester as a disjointed list of "dos and don'ts" and then hopefully applied to laboratory work. Similarly, information literacy is more than depending on a search box that seemingly magically locates the most pertinent authoritative publications from among millions on the Internet based on a few key terms. Safe, informed, laboratory-based chemical research requires the ability to assess the applicability of previously learned 'rules' in different

situations and apply them to the work at hand. Conscious application of 
knowledge is common to practicing laboratory safety and information management and is not an intuitive skill. Effective teaching of these skills involves expanding the knowledge base from rules to assessment techniques and shifting classroom focus from input to outcomes more typical of research and discovery science.

Effective chemical safety and information literacy education for undergraduates can create new cognitive categories in a learning process known as accommodation. Accommodation occurs when a new experience causes a student to alter or maybe even completely rearrange their current thinking. ${ }^{9}$ Assimilation adds new information to existing cognitive categories. Once an individual has established cognitive categories, new information can be added to those categories in the future with less learning effort. ${ }^{9}$ In a simple analogy, accommodation is building a mental box and assimilation is putting things in the box. It is easier to gather and hold onto useful ideas if first there is a box built to put them into. By not directly addressing chemical safety and information literacy as part of the undergraduate curriculum, we are not allowing our future chemists to form genuine cognitive accommodation categories around these subdisciplines impacting their daily lives and future careers as laboratory researchers.

The current trend in undergraduate chemical education is to get students into the research lab as early as possible. At the undergraduate level, students do not yet have much exposure to the scientific research context. Undergraduate programs are focused on familiarizing students with the fundamental principles and models that differentiate the scholarly disciplines. Familiarity with research techniques is developed in lab sections, but the skills for putting these into practice to address novel research problems as expected in a research setting are not intuitive. This challenge for students is further reflected in the need to incorporate information and safety concepts into the research process. The question of how to translate concepts to procedures can be addressed in successive levels of learning outcomes, starting with formulation of rules followed by rationale and finally processes and risk assessment tools.

The underlying frameworks in laboratory safety and information literacy and their application to chemical research could constitute a dedicated course on professional, life-long skill building. However, barriers such as limits on major hours and lack of faculty with the expertise to teach these specialized topics are sometimes cited as reasons why it is difficult to add a course on chemical safety and/or information literacy as a curriculum item on par with the other subdisciplines of chemistry. This chapter offers an approach for incorporating laboratory safety knowledge and information literacy concepts into existing classes. 


\section{Evolving Basic Lab Safety - From Rules to Understanding}

In introductory chemistry labs, risk has traditionally been controlled by having students adhere to well-established safety rules addressing several basic categories of hazard (Figure 1$)^{10}$ and utilizing chemicals and procedures which have hazards that are well classified.

CATEGORIES FOR BASIC SAFETY RULES

- PROPER CONDUCT \& BEHAVIOR

- PROPER LAB ATTIRE

- SAFE HANDLING OF CHEMICALS

- SAFE HANDLING OF EQUIPMENT

- SAFETY EQUIPMENT \& PPE

- PROPER HOUSEKEEPING

- PROPER HYGIENE

- EMERGENCY PREPAREDNESS

Figure 1 - Grouping of Basic Safety Knowledge

Undergraduate students in their first chemistry courses do not have the necessary competencies to assess hazards, determine risk, and/or locate reliable information to control risk. It would be negligent for an instructor to allow students to enter their first chemistry laboratory with only the warning: "Be careful, evaluate the hazards and determine the risk prior to work, and use your common sense." Without prior experience, it is difficult to recognize hazards or know how to assess risk. How can information be evaluated if there is no knowledge base?

Rules are useful reminders as outcomes of previous thought, but should not be presented as a disjointed list of those thoughts. Giving a student a list and imploring them to behave accordingly will not promote learning. As shown in Figure 2, basic rules or guidelines can be used to help develop chemical safety competencies. In the chemical safety learning process, accommodation starts with the safety rules which create specific cognitive categories (boxes). Explanation of the rules, lessons learned, historical context, and risk assessment (parsing new ideas into those categories) evolves the rule through assimilation and develops chemical safety competencies. If students are given little additional information beyond the rules to assimilate into their categories, learning may stop at accommodation. 


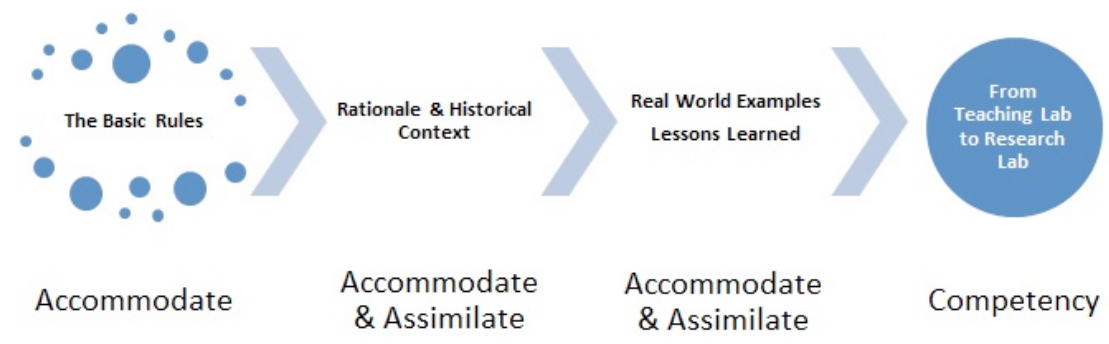

Figure 2 - Use Rules to Create Chemical Safety Competencies

Table 1 shows some examples of rule rationale that can be presented as one introduces a lab class to the rules. As a pre-laboratory assignment, each student could be assigned two or three common rules and asked to research the rationale for the rule. Their results would be discussed prior to the lab - including reliability of the sources of information used in the searches. Exercises like this would make the rule concept more concrete and assist with the assimilation process. Table 2 illustrates the translation of these ideas for a few rules.

After a few laboratory courses, students have developed some basic knowledge about hazards, but have relied on following rules to minimize risk. As experiments and processes become more advanced in upper level undergraduate courses and research, the hazards will become greater, more complicated, and more complex. The rules must evolve from a list of "dos and don'ts" to learning about assessing risk based on the hazards, as illustrated in Figure 3 by the process of selecting personal protective equipment (PPE).

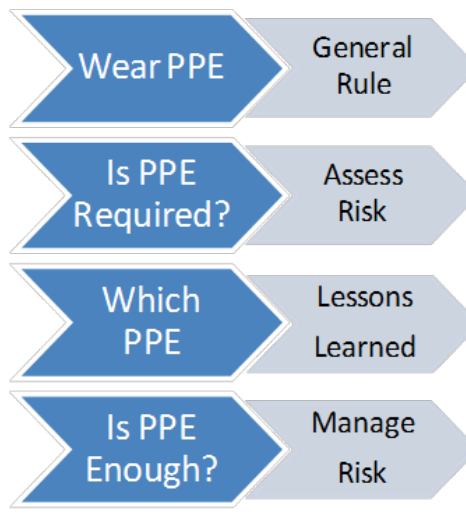

Figure 3 - Evolution of a Rule 
Table 1 - A Few Safety Rules Explained

\begin{tabular}{|l|l|}
\hline \multicolumn{1}{|c|}{ Common Rule } & \multicolumn{1}{c|}{ Rationale for Rule } \\
\hline $\begin{array}{l}\text { Always wear chemical splash } \\
\text { goggles when there is a possibility } \\
\text { of chemical splash. }\end{array}$ & $\begin{array}{l}\text { Your eyes are irreplaceable. You cannot } \\
\text { always predict a potential splash hazard. } \\
\text { The risk from splash increases with } \\
\text { multiple workers and procedures occurring } \\
\text { in the lab. }\end{array}$ \\
\hline $\begin{array}{l}\text { Confine long hair and loose } \\
\text { clothing. }\end{array}$ & $\begin{array}{l}\text { Hair and loose clothing can easily become } \\
\text { entangled in moving parts or catch fire } \\
\text { when using Bunsen burners. }\end{array}$ \\
\hline $\begin{array}{l}\text { Never work alone in the } \\
\text { laboratory. }\end{array}$ & $\begin{array}{l}\text { Incidents are usually unexpected. When } \\
\text { they do happen, time is critical. Someone } \\
\text { knowledgeable about the work should be } \\
\text { working nearby to assist with an } \\
\text { emergency. }\end{array}$ \\
\hline $\begin{array}{l}\text { Never consume any food or } \\
\text { beverage when you are in a } \\
\text { chemical laboratory. Do not chew } \\
\text { gum or tobacco, and do not smoke } \\
\text { or apply cosmetics in the } \\
\text { laboratory. }\end{array}$ & $\begin{array}{l}\text { Food and products can become } \\
\text { contaminated. Any of these activities can } \\
\text { inadvertently transfer chemicals to your } \\
\text { mouth or skin. }\end{array}$ \\
\hline $\begin{array}{l}\text { Always wash your hands and } \\
\text { arms with soap and water before } \\
\text { leaving the laboratory, even if you } \\
\text { wore gloves. }\end{array}$ & $\begin{array}{l}\text { In the lab, contact with chemicals is always } \\
\text { a possibility and contact may be } \\
\text { inadvertent and go initially unnoticed. }\end{array}$ \\
\hline & $\begin{array}{l}\text { Pipetting by mouth directly exposes the } \\
\text { worker to ingestion of chemicals. This } \\
\text { technique was discontinued long ago in the } \\
\text { US, but it is possible that students may } \\
\text { come from countries where this might still } \\
\text { be practiced. }\end{array}$ \\
\hline $\begin{array}{l}\text { Never pipet by mouth. Always aid or suction bulb. } \\
\text { laboratory without proper } \\
\text { authorization. }\end{array}$ & $\begin{array}{l}\text { There is no justification for personal use of } \\
\text { chemicals. Removing chemicals from a } \\
\text { laboratory is unethical and may be illegal. }\end{array}$ \\
\hline $\begin{array}{l}\text { Report violations of your } \\
\text { laboratory's safety rules to your } \\
\text { instructor-you could save their } \\
\text { lives and your own. }\end{array}$ & $\begin{array}{l}\text { Safety is everyone's responsibility. Safety } \\
\text { concerns are learning opportunities for } \\
\text { everyone when presented without blame. }\end{array}$ \\
\hline
\end{tabular}


Table 2 - Rules to Risk

\begin{tabular}{|l|l|}
\hline \multicolumn{1}{|c|}{$\begin{array}{c}\text { Rule Based } \\
\text { (Instructional Labs) }\end{array}$} & \multicolumn{1}{c|}{\begin{tabular}{c}
\multicolumn{1}{c}{ Risk Based } \\
(Research Labs)
\end{tabular}} \\
\hline $\begin{array}{l}\text { Follow all safety instructions } \\
\text { carefully. }\end{array}$ & $\begin{array}{l}\text { Do not change procedures without careful } \\
\text { thought as to how this may affect the } \\
\text { hazards of the chemicals or processes } \\
\text { being used. Following instructions is very } \\
\text { important, but action without thought can } \\
\text { be dangerous also. Discuss controlling } \\
\text { change. }\end{array}$ \\
\hline $\begin{array}{l}\text { Never perform unauthorized } \\
\text { experiments. }\end{array}$ & $\begin{array}{l}\text { Be sure to realize your limitations and ask } \\
\text { for clarification when you don't } \\
\text { understand something. Follow any } \\
\text { laboratory specific Standard Operating } \\
\text { Procedures (SOP) without deviation. }\end{array}$ \\
\hline $\begin{array}{l}\text { Become thoroughly acquainted } \\
\text { with the location and use of } \\
\text { safety equipment and facilities } \\
\text { such as exits, safety showers, } \\
\text { and eyewash fountains. }\end{array}$ & $\begin{array}{l}\text { Become an active participant in the } \\
\text { maintenance of the safety and engineering } \\
\text { equipment (e.g. hoods) in the laboratory. } \\
\text { Assign tasks to various lab workers on a } \\
\text { rotating basis. Ensure that showers, } \\
\text { eyewashes, and exits are never blocked. }\end{array}$ \\
\hline $\begin{array}{l}\text { Before undertaking any } \\
\text { laboratory work, become } \\
\text { familiar with the hazards of the } \\
\text { chemicals involved. }\end{array}$ & $\begin{array}{l}\text { Perform a hazard analysis or risk } \\
\text { assessment using standard methods such } \\
\text { as those presented in "Identifying and } \\
\text { Evaluating Hazards in Research } \\
\text { Laboratories"11 to uncover hazard and } \\
\text { reduce risk. }\end{array}$ \\
\hline
\end{tabular}

\section{Incorporating Chemical Safety and Information Literacy into Chemistry Curriculum}

The reactivity of chemicals is the focus of most chemical study and creating a completely 'safe' fictitious laboratory experience would necessitate elimination of the most active participants in wet laboratory processes including many organic solvents and oxidizing substances. Educating chemists that have never handled chemicals may be safe, but would produce a very hazardous workforce! In addition to chemicals, there are many other hazards that are likely to be encountered in a laboratory. Any active process involving manipulation of equipment, handling stock bottles and storage containers, and operating at temperatures and pressures other than ambient, presents potential dangers to operators. There are many challenges that face the incorporation of 
safety concepts into undergraduate chemistry activities, but chemists must be taught how to locate information, determine hazards, and reduce risk to an acceptable level that has been predetermined based on worker experience and/or institutional guidelines. Putting safety concepts to work in a research laboratory setting hinges on the ability of the students to evaluate and assimilate data and information related to the work at hand.

Teaching undergraduate students how to create a risk assessment tool takes learning to the next level by incorporating new conceptual knowledge into the undergraduate curriculum and facilitating assimilation of ideas about safety and authoritative information beyond the basic rules. Performing a risk assessment on a chemical or task requires students to use information to recognize, understand, and prioritize hazards and then consider ways to eliminate or reduce risk to a level that enables work to proceed safely. In this way, risk assessment combines more advanced concepts of chemical safety (toxicology, controls, physical hazards of chemicals, PPE selection, etc.) with chemical information skills. The CPT report on Chemical Information Skills states that, "...the incorporation of exercises that require students to develop familiarity with the chemical literature should be an integral part of the chemistry program." ${ }^{12}$ Students must go to the literature to gather information that enables the determination of hazards and the evaluation of risk. Creating a risk assessment tool is a perfect exercise to fulfill the CPT informational skill requirement while also teaching risk assessment methodology and critical thinking.

Learning outcomes benefit students by focusing their attention onto what is important. ${ }^{13}$ Learning outcomes also benefit research mentors by ensuring that students have the competencies to work with process specific hazards. The safety professional and librarian contribute by establishing the criteria that will measure the success of the training. A well-written learning objective should contain three components: ${ }^{9}$ desired outcome, or what should be expected of the trainee after training; conditions under which the expected outcome will take place; and standards or criteria that will define an acceptable outcome. Three examples of assignments which can evaluate the quality of an assignment and have specific, assessable learning objectives are presented in Figure 4. For each of these exercises, students are directed to very specific information source.

Basic hazard potential of chemicals is communicated via the classification assigned by the Globally Harmonized System (GHS) symbols and codes that can be found on Safety Data Sheets (SDSs, formerly known as MSDSs) and on chemical supplier bottles and packages. ${ }^{14}$ The National Institutes of Health $(\mathrm{NIH})$ and other agencies provide many databases for finding more extensive chemical property, safety and toxicological information, most of which are indexed by the ChemID Advanced search tool. ${ }^{15}$ The National Academy of Sciences (NAS) recommends use of a Laboratory Chemical Safety Summary (LCSS) to guide chemical information gathering appropriate to the research lab setting. ${ }^{16}$ The National Library of Medicine (NLM) PubChem database compiles 
data into LCSSs from SDSs and other authoritative safety data sources. ${ }^{17}$ A longer list of information databases can be found at the NLM Enviro-Links for Lab Safety guide ${ }^{18}$ and in Appendix C.
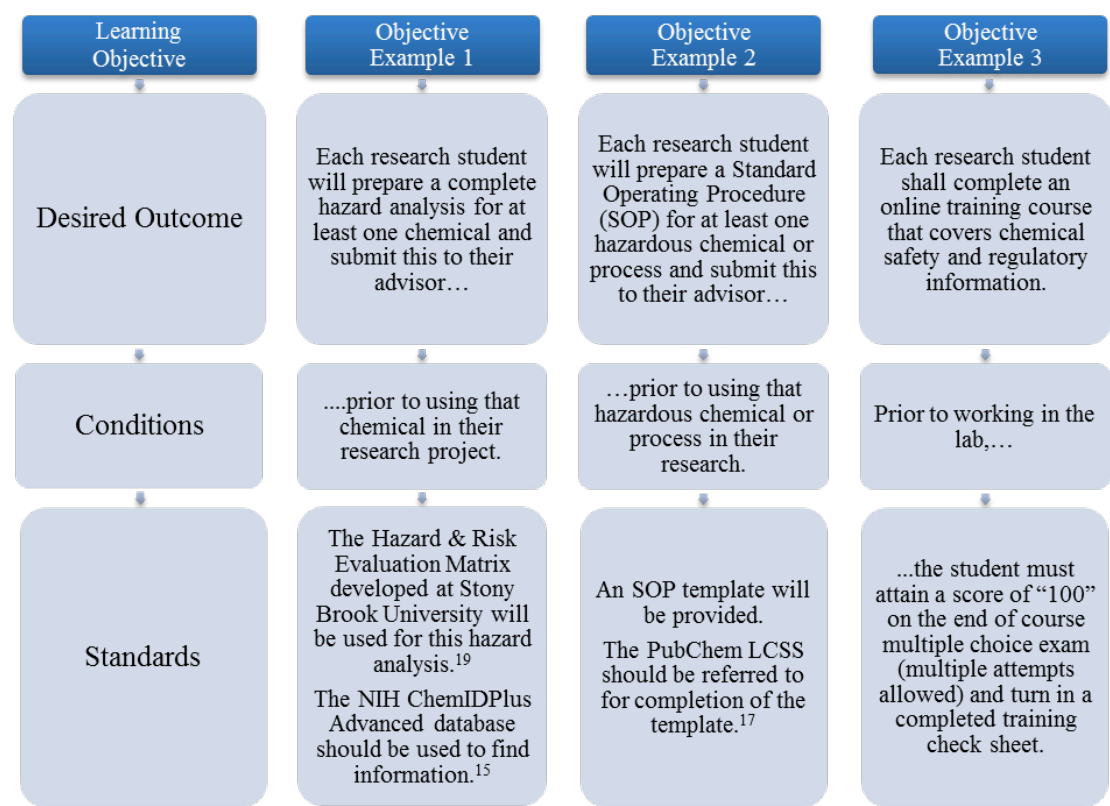

Figure 4 - Learning Objective Examples with Components

The Hazard \& Risk Evaluation Matrix from Stony Brook University is a particularly good tool to use for teaching informational skills relevant to risk assessment. ${ }^{19}$ Information is required that cannot be found on many SDSs. Additionally, for many substances, various physical values will often not be published in databases and students have to try and find primary sources. What students often discover is that many chemicals are not well studied and that toxicological and regulatory values are lacking. Students learn from this that "no data available" and "safe" are not synonymous. In fact, if the indicated information required for filling in the matrix cannot be located or is not known (flash point for example), students must assign a high level of risk for use since the hazard is an unknown.

As in the case of assessing safety concerns, entry-level undergraduate students have few competencies developed for managing the primary research literature beyond simple keyword search. Generally, students need to understand where to find authoritative information, how to distinguish scholarly from nonscholarly sources, include references in papers without plagiarizing, and properly construct bibliographies. These competencies have been outlined by the 
Association of College and Research Libraries (ACRL) as part of the research cycle. ${ }^{20}$ Stuart and McEwen previously demonstrated the alignment of this cycle with the risk assessment process (iRAMP). ${ }^{21}$ An example risk assessment information search process is shown in Table 3. A sample workflow for researching the flammability of glacial acetic acid is illustrated in Figure 5, including documenting sources. The additional data on vapor density collected via PubChem LCSS could prove useful in preventing a potential fire by informing the user about flammable vapors accumulating in low areas.

Evaluating the authority and quality of data is of particular importance in conducting risk assessment. Applying data inappropriately could result in a lab mishap where a worker is exposed or injured. For example, if a substance becomes hazardous upon decomposition, the temperature at which this would happen is critical for working safely with that chemical. Relying on an inaccurately reported decomposition temperature could put workers at risk. The updated 2015 ACRL Information Literacy Framework emphasizes that the authority of information is contextual and thus all sources of information have some bias and scope limitation depending on their purpose. ${ }^{22}$ Many chemical safety databases from NLM aggregate information from a variety of agency sources with a diversity of intended audiences and needs. The information in any one source may not be targeted for all types of use and the user may not realize when information is missing or irrelevant for their context. The profile of information included in SDSs commonly available in many labs is primarily targeted towards transportation of large quantities of chemical materials and may not be fully informative about use of a chemical in a lab setting, such as the example given for the flammability of acetic acid. To use information from any of these sources, researchers need to develop relevant criteria for the conditions of their research project, such as the Evaluation Matrix offered by Stony Brook. $^{19}$

During this process, students must ascertain if the data they find is at the right scale, for the right forms of chemicals and types of equipment, and reported under similar conditions as specified in their own lab procedures. They may need to convert units, or follow the original citation to determine if the data is appropriate for their project. The importance of checking multiple sources to determine the accuracy of data becomes evident. For example, ChemIDPlus Advanced and PubChem LCSS both include data from multiple sources for comparison. ${ }^{15,17}$ Suggested performance indicators and learning outcomes have formed the basis of many rubrics for incorporating these evaluation practices into class exercises. ${ }^{23}$ Further guidance for educators on skill development in using chemistry literature are provided in the CPT Supplemental Guidelines for Chemistry Literature, ${ }^{12}$ and the Information Competencies for Chemistry Undergraduates from the Special Libraries Association. ${ }^{24}$ 
Table 3 - Information Search Process for Risk Assessment

\begin{tabular}{|c|c|c|}
\hline Step & Task $^{20}$ & Risk Assessment Examples \\
\hline Scope & $\begin{array}{l}\text { determine the } \\
\text { nature and } \\
\text { extent of } \\
\text { information } \\
\text { needed }\end{array}$ & $\begin{array}{l}\text { - Hazard classes (GHS, NFPA) } \\
\text { - Physical \& chemical properties (flash } \\
\text { point, boiling point, vapor pressure, vapor } \\
\text { density, pH) } \\
\text { - Reactivity and incompatibility } \\
\text { - Toxicity indicators (e.g., Median Lethal } \\
\text { Dose - LD } \text { L }_{50} \text { ) } \\
\text { - Exposure limits }\end{array}$ \\
\hline Collect & $\begin{array}{l}\text { access needed } \\
\text { information } \\
\text { effectively and } \\
\text { efficiently }\end{array}$ & $\begin{array}{l}\text { - SDSs, usually available from major } \\
\text { chemical suppliers (e.g., Sigma) } \\
\text { - Toxicity and property information from } \\
\text { agency safety resources } \\
\text { - Reactivity information specialized, often } \\
\text { only available in HSDB }\end{array}$ \\
\hline Evaluate & $\begin{array}{l}\text { evaluate } \\
\text { information and } \\
\text { sources } \\
\text { critically and } \\
\text { incorporate } \\
\text { selected } \\
\text { information } \\
\text { into knowledge } \\
\text { base and value } \\
\text { system }\end{array}$ & $\begin{array}{l}\text { - Do the sources have all the information } \\
\text { - Aou are looking for? } \\
\text { sources or original chemical } \\
\text { manufacturer? } \\
\text { - Are the data points for the right of form } \\
\text { and concentration of the chemical (pure } \\
\text { vs. dilute mixture)? } \\
\text { - Do the data points have units, are they at } \\
\text { the correct scale? } \\
\text { If you have data from more than one } \\
\text { source, do they agree or disagree? } \\
\text { - Do you recognize your knowledge "gaps" }\end{array}$ \\
\hline Apply & $\begin{array}{l}\text { use information } \\
\text { effectively to } \\
\text { accomplish a } \\
\text { specific } \\
\text { purpose }\end{array}$ & $\begin{array}{l}\text { Have you considered properties at higher } \\
\text { temperature or pressure (in case of over- } \\
\text { heating or pressure build-up)? } \\
\text { - Have you considered related properties } \\
\text { such as vapor density or fine powder that } \\
\text { could further impact handling? }\end{array}$ \\
\hline Document & $\begin{array}{l}\text { access and use } \\
\text { information } \\
\text { ethically, } \\
\text { legally and in } \\
\text { the context of } \\
\text { cultural norms }\end{array}$ & $\begin{array}{l}\text { - Did you include all reference data points } \\
\text { used in your risk assessment? } \\
\text { - Have you cited all references of data used } \\
\text { in your assessment? }\end{array}$ \\
\hline
\end{tabular}




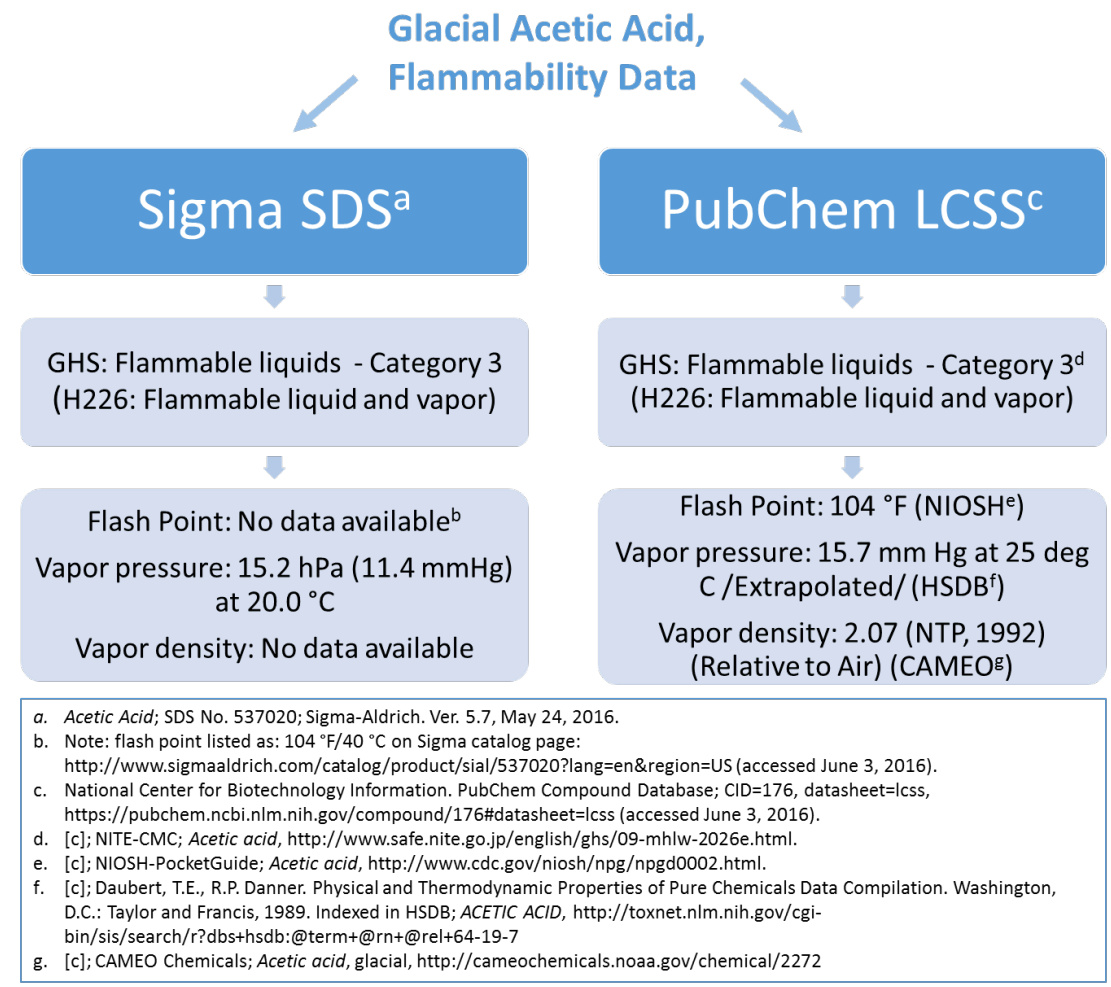

Figure 5 - Flammability Data Search Process for Glacial Acetic Acid

\section{Integrating a Job Hazard Analysis Tool into an Existing Course}

In 2015, the ACS Committee on Chemical Safety released their final report document, "Identifying and Evaluating Hazards in Research Laboratories." 11 Chapters 8-12 in this document give general guidance on five specific tools (Control Banding, Job Hazard Analysis, What-if Analysis, Checklists, and Standard Operating Procedure Development). Students can be taught to create and use any of the tools, but the Job Hazard Analysis (JHA) lends itself particularly well to both teaching and learning risk assessment and information literacy in the classroom setting. The JHA may go by various names all having similar formats and use, but the commonly recognized version today is the one that OSHA has publicized. ${ }^{25,7}$

In fall 2012, an assignment using the JHA was integrated into the senior capstone course (CHE 4000) at Appalachian State University. This course has 
one to three sections each semester, depending on the number of students registered. For the period of assessment reported on in Appendix B, the enrollment was between 20 and 40 junior and senior chemistry majors each semester. All students in the ACS-certified degree track are placed into a "research active" section. The other students are grouped together in sections for those not actively engaged in research. The reason for this is that the assignments for the research proposals will be structured differently for students actively engaged in research.

The JHA was incorporated into research proposal activity because it was realized that teaching risk assessment could increase chemical safety, information literacy, and provide data to demonstrate the program effectiveness with regard to teaching chemical safety. From the course syllabus:

The student will review of the background literature on the chosen topic. Working closely with the course instructor and faculty advisor, the student will develop a research proposal that will be presented to the faculty of the Department of Chemistry in written form and as a poster presentation following guidelines published by the American Chemical Society. You will also write a curriculum vitae (CV), a cover letter, a personal statement, a job hazard analysis and a research proposal that could be submitted to the Office of Student Research (OSR). Specific skills of preparing and defending a research proposal will be common to all students who complete the course. ${ }^{26}$

The JHA is a particularly good tool to use for this assignment because it forces students to think about the task from a birds-eye view. To facilitate constructive critiquing when grading and for departmental assessment, each student completes the same assignment: Prepare one liter of a $1000 \mathrm{ppm}$ stock solution of copper(II) ions from copper solid (CAS 7440-50-8) and concentrated nitric acid (CAS 7697-37-2) for Atomic Absorption Standards. A completed JHA for this process is shown in Appendix A.

To kick off the assignment, the Chemical Hygiene Officer (CHO), a chemistry department faculty member, attends the capstone course as a guest lecturer. At this time, the students are introduced to the psychology of risk response, various types of hazards, risk assessment, the hierarchy of controls, and the structure of a JHA tool. Students are given a specific template to use, instructions for filling out the template, and a list of credible websites where relevant information can be located. Should the school have a librarian familiar with the required information sources, that person could be invited to the initial lecture to discuss reliable sources. Students are typically given 2 to 3 weeks to complete their initial draft.

Dividing the process into an appropriate number of meaningful steps and assigning an appropriate risk level to those steps often proves particularly 
difficult for students. For example, the student might give the first step of the procedure as, "Pour $20 \mathrm{~mL}$ of concentrated nitric acid into the beaker." This completely bypasses a step which has a significant layer of hazard - removing the acid bottle from storage and transporting it to the hood or counter.

For this exercise, risk must be reported both quantitatively and qualitatively. Various tools are available in the industry to determine a "risk" value based on three parameters - severity of consequence, likelihood, and frequency of exposure. For this assignment, students use a tool that assigns numerical values for the three factors on scales ranging from unlikely or minor to continuous or catastrophic. A semi-quantitative value may be calculated by multiplying the assigned values to estimate risk. ${ }^{27}$ In most cases, risk determination is a new concept for the students and can be exaggerated or underestimated easily based on their nascent judgment and limited knowledge of hazards. Grading on student assigned risk values is based on relativity for this exercise. Students must assign the greatest numerical values to the high risk steps and they are not penalized if the numerical values on all steps are inflated, so long as the riskiest step is assigned the highest numerical value.

Students in the capstone course who are actively performing research must also develop a JHA later in the semester for a chemical or task being used in their research project. In this way, these students must apply what they have learned in the initial JHA assignment to an actual laboratory project. This research JHA is a graded component of their final senior research proposal. Students are encouraged to discuss their research JHA with their advisor and obtain an approval signature. Again, this is not a new idea. In 1964, Livingston argued that risk assessment (or what he refers to as "safety considerations") should be added to research proposals. As defined by Livingston, "Safety considerations are those mental processes that determine if hazards to health or property values are likely to be involved in a proposed course of action, and evaluate the steps." ${ }^{6}$

\section{Assessing Learning to Demonstrate Acquired Knowledge and Skills}

Once the draft is submitted, it is critiqued with comments for improvement by the CHO. Students are given the opportunity to improve their assignment based on the feedback before resubmitting it for grading. If desired, students may schedule appointments with the $\mathrm{CHO}$ to review their critiqued draft before preparing their final tool. How reflection aids the accommodation to assimilation process for learning risk assessment is discussed in Appendix B. The purpose of this assignment is not to produce a perfect assessment tool, but to teach students how to think about laboratory hazards, risk, controls (or barriers), and use research information to support their ideas. 
The student JHAs are graded on a range of criteria such as considering the hazards associated with the chemical and equipment, the method of risk assessment, and the selection of risk management controls (summarized in Table 4). The full grading rubric used to assess competence is shown in Appendix D. This assignment has been used for the safety component of our departmental program assessment since the fall semester of 2014.

For departmental assessment purposes, the JHA assignment in all sections of the capstone course addresses our program goal, "To acquire a thorough knowledge of laboratory methods and techniques." The student learning outcome (SLO) for this goal that is being assessed is, "Students will evaluate and manage experimental hazards and assess risk." The SLO will be met if, "Seventy percent $(70 \%)$ of the students score a sum of at least 30 points $(60 \%$ or "competent") out of a possible 50 points on their completed assignment." This SLO has been assessed for a total of five semesters from fall semester of 2014 through the spring semester of 2016. Evaluation of the assessment is reported in Appendix B.

Table 4 - JHA Grading Criteria

\begin{tabular}{|l|l|}
\hline \multicolumn{1}{|c|}{ Major Components } & \multicolumn{1}{c|}{ Ideal Documentation } \\
\hline Header \& Footer Information & $\begin{array}{l}\text { Job location, date, person preparing the } \\
\text { tool, PI signature }\end{array}$ \\
\hline Equipment \& Chemicals Required & $\begin{array}{l}\text { Engineering controls, equipment, } \\
\text { chemicals, PPE, ER }\end{array}$ \\
\hline Hazards Checklist & Chemical, physical and health hazards \\
\hline Steps Accurately Describe the Task & $\begin{array}{l}\text { Adequate number provided, major } \\
\text { steps identified }\end{array}$ \\
\hline Personal Protective Equipment & $\begin{array}{l}\text { Type and use well defined and } \\
\text { documented }\end{array}$ \\
\hline Significant Hazards Identified & $\begin{array}{l}\text { Chemical hazards, process hazards, } \\
\text { equipment hazards }\end{array}$ \\
\hline Risk Determination & $\begin{array}{l}\text { Method stated quantitatively and } \\
\text { qualitatively and appropriately assessed } \\
\text { for each step }\end{array}$ \\
\hline Controls Sufficient to Lower Risk & $\begin{array}{l}\text { Exposure controls, engineering } \\
\text { controls, administrative, ER controls, } \\
\text { reactivity, environmental/waste, } \\
\text { documentation }\end{array}$ \\
\hline
\end{tabular}

Overall, the response to this assignment from the students has been very positive. Students will often ask at the end of the semester, "Why don't we learn 
this earlier in the major?" One student who went on to perform a summer

internship wrote back saying,

We had a company-wide Safety Trivia Day where we got into groups of 4 or 5. It was mainly the interns vs. the employees. They were simple questions about PPE, what to do if you encounter a spill, what to do in cases of emergency, and a few questions based on all of the things we went over in the safety class for research. Two of the questions specifically were "What does GHS stand for?" and "What does JHA stand for?" I highly doubt that many pharmaceutical companies have a Trivia Day, but I'm sure many of them require their employees to know these kinds of things. So, thanks again for teaching me these things in the research safety class! $!^{28}$

After consideration of these types of comments, the department has moved the JHA assignment to CHE 3000, a junior level introduction to chemical research course. Students in the ACS-certified degree track will continue to complete a JHA based on their research in the capstone course (CHE 4000).

\section{Conclusion}

There is a widely held belief that students who graduate with an undergraduate degree in chemistry will have acquired a broad knowledge of a number of supporting skills, including chemical safety, information literacy and ethics, and that this knowledge will have been gained from a cumulative exposure to general rules and various experimental procedures. However, observations from thirty years of teaching undergraduate chemistry majors indicate that it is currently unlikely students have been exposed to complex chemical safety subjects such as risk analysis, hazard determination, toxicant exposure control (aside from putting on gloves and goggles), understanding regulatory agencies and regulations, and how to find peer-reviewed information on toxicants. A dearth of recorded documentation of safety planning in academic research labs suggests it is regarded as secondary to designing chemical procedures at the research level.

Future chemists must learn to work safely with chemicals. Changing culture does not happen spontaneously - or even quickly. The concepts of "safety culture" or "information literacy" are not new and chemical educators must be part of their advancement in the curriculum from middle school on. Educators must be willing to incorporate and embrace the proactive paradigm for teaching both chemical safety and information literacy in as many different ways as possible. If we are expecting a paradigm shift in academic ethical culture to occur, new competencies must be taught as part of the curriculum. Learning 
these critical thinking and application skills and knowledge should be treated no differently than any other subject.

Students need to learn to effectively recognize hazards, assess and minimize the risks presented by those hazards, and prepare for emergencies. ${ }^{29}$ They should be exposed to chemical safety early and often to facilitate accommodation, which will, in turn, make the assimilation of new knowledge easier later. Students who develop competencies in chemical safety as undergraduates early in their research career creates researchers with a strong "safety culture" who can assimilate more complex chemical safety concepts easier as they progress in their career. Transfer of knowledge into the lab can be more successful if research advisors and mentors understand chemical safety learning objectives and encourage student learning. The theory of risk assessment should be taught to every future chemist. Universities should not only be teaching chemical safety, they should be producing chemistry graduates with concentrations in chemical safety or occupational health \& safety who have the knowledge and skill to make informed decisions when assessing the hazards of a laboratory. 


\section{Appendix A - Example JHA for Copper Digestion}

Table A1 - JHA (Completed Example)

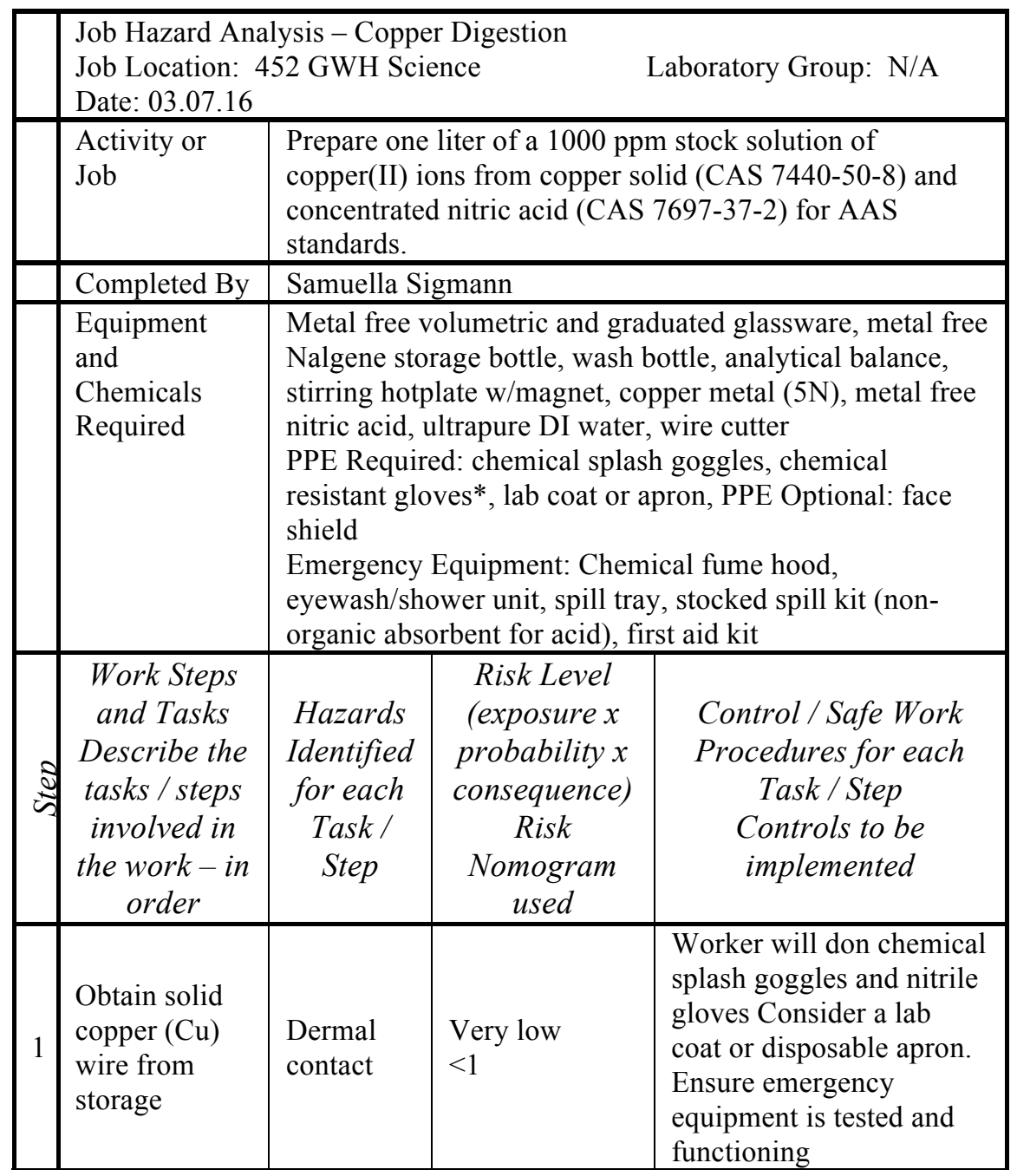




\begin{tabular}{|c|c|c|c|c|}
\hline 2 & $\begin{array}{l}\text { Weigh solid } \\
\text { copper }(\mathrm{Cu}) \\
\text { wire on } \\
\text { analytical } \\
\text { balance }\end{array}$ & $\begin{array}{l}\text { Dermal } \\
\text { contact } \\
\text { Cut }\end{array}$ & $\begin{array}{l}\text { Very low } \\
<1\end{array}$ & $\begin{array}{l}\text { Worker will don chemical } \\
\text { splash goggles and nitrile } \\
\text { gloves Consider a lab } \\
\text { coat or disposable apron. } \\
\text { Use body awareness } \\
\text { when cutting copper wire }\end{array}$ \\
\hline 3 & $\begin{array}{l}\text { Transfer } \mathrm{Cu} \\
\text { wire to a } 250 \\
\text { mL beaker }\end{array}$ & $\begin{array}{l}\text { Same as } \\
\text { Step } 1\end{array}$ & Same as Step 1 & Same as Step 2 \\
\hline 4 & $\begin{array}{l}\text { Place beaker } \\
\text { containing } \mathrm{Cu} \\
\text { on stirring } \\
\text { hotplate in } \\
\text { hood, add } \\
\text { magnet }\end{array}$ & $\begin{array}{l}\text { Same as } \\
\text { Step } 1\end{array}$ & Same as Step 1 & $\begin{array}{l}\text { Same as Step 2, PLUS } \\
\text { clear hood of all } \\
\text { unnecessary equipment } \\
\text { and chemicals, especially } \\
\text { organic solvents }\end{array}$ \\
\hline 5 & $\begin{array}{l}\text { Remove stock } \\
\text { bottle of } \\
\text { concentrated } \\
\text { nitric acid } \\
\text { from storage }\end{array}$ & $\begin{array}{l}\text { Chemical } \\
\text { splash - } \\
\text { Corrosive; } \\
\text { eye \& } \\
\text { skin } \\
\text { damage; } \\
\text { inhalation } \\
\text { (toxic } \\
\text { gas); } \\
\text { Chemical } \\
\text { spill; } \\
\text { Oxidizing } \\
\text { liquid }\end{array}$ & $\begin{array}{l}\text { Moderate } \\
>20 \text {, but }<50\end{array}$ & $\begin{array}{l}\text { Nitric acid is very } \\
\text { reactive. Do not } \\
\text { underestimate this hazard. } \\
\text { Include and review SDS } \\
\text { as a control in this JHA. } \\
\text { Wear all PPE as above, } \\
\text { HOWEVER nitrile does } \\
\text { not protect well for } \\
\text { concentrated acid - } \\
\text { double glove, add } \\
\text { polyethylene or butyl } \\
\text { rubber. } \\
\text { Note location of and } \\
\text { visually inspect spill kit } \\
\text { w/ neutralizing material } \\
\text { Review ER procedures } \\
\text { If large spill occurs i.e. } \\
2.5 \text { L bottle, evacuate and } \\
\text { notify }\end{array}$ \\
\hline
\end{tabular}




\begin{tabular}{|c|c|c|c|c|}
\hline 6 & $\begin{array}{l}\text { Transfer } \sim 50 \\
\text { mL of con } \\
\text { nitric to } 250 \\
\text { beaker }\end{array}$ & $\begin{array}{l}\text { Chemical } \\
\text { splash - } \\
\text { Corrosive; } \\
\text { eye \& } \\
\text { skin } \\
\text { damage; } \\
\text { inhalation } \\
\text { (toxic } \\
\text { gas); } \\
\text { Chemical } \\
\text { spill; } \\
\text { Oxidizing } \\
\text { liquid }\end{array}$ & $\begin{array}{l}\text { Moderate } \\
>20 \text {, but }<50\end{array}$ & $\begin{array}{l}\text { Same as step } 5 \text { plus work } \\
\text { on spill tray }\end{array}$ \\
\hline 7 & $\begin{array}{l}\text { Add } 30 \mathrm{~mL} \text { of } \\
\text { concentrated } \\
\text { nitric acid (16 } \\
\left.\mathrm{M} \mathrm{HNO}_{3}\right) \text { Stir } \\
\text { as needed }\end{array}$ & $\begin{array}{l}\text { Chemical } \\
\text { splash - } \\
\text { corrosive; } \\
\text { eye } \\
\text { damage; } \\
\text { inhalation } \\
\left(\mathrm{NO}_{2} \text {, }\right. \\
\text { toxic gas) } \\
\text { Chemical } \\
\text { spill } \\
\text { Oxidizing } \\
\text { liquid }\end{array}$ & Low $<10$ & $\begin{array}{l}\text { Wear all PPE as above, } \\
\text { HOWEVER nitrile does } \\
\text { not protect well for } \\
\text { concentrated acid - } \\
\text { double glove, add } \\
\text { polyethylene or butyl } \\
\text { rubber } \\
\text { WORK IN FUME HOOD } \\
\text { - lower sash; set up at } \\
\text { least 6" inside } \\
\text { Stir slowly with magnet } \\
\text { on stir plate to displace } \\
\text { nitrogen dioxide }\left(\mathrm{NO}_{2}\right) \text { a } \\
\text { toxic brown gas. Cover } \\
\text { with watch glass if } \\
\text { needed. } \\
\text { Beaker graduations offer } \\
\text { sufficient accuracy, so } \\
\text { minimize cleaning by not } \\
\text { measuring with other } \\
\text { equipment. }\end{array}$ \\
\hline 8 & $\begin{array}{l}\text { Check for } \\
\text { reaction } \\
\text { completion - } \\
\text { Ensure that } \\
\text { Cu wire has } \\
\text { completely } \\
\text { dissolved }\end{array}$ & $\begin{array}{l}\text { Chemical } \\
\text { splash - } \\
\text { corrosive; } \\
\text { eye } \\
\text { damage; } \\
\text { Chemical } \\
\text { spill }\end{array}$ & $\begin{array}{l}\text { Moderate }>10 \\
\text { but }<50\end{array}$ & $\begin{array}{l}\text { Ensure that gas } \\
\text { production has stopped } \\
\text { before removing from } \\
\text { fume hood } \\
\text { Add face shield if close } \\
\text { inspection of reaction } \\
\text { beaker is required - do } \\
\text { not hold over body }\end{array}$ \\
\hline
\end{tabular}




\begin{tabular}{|c|c|c|c|c|}
\hline 9 & $\begin{array}{l}\text { Add } 300 \mathrm{~mL} \\
\text { of DI water to } \\
1 \mathrm{~L} \\
\text { volumetric } \\
\text { flask }\end{array}$ & Cuts & Low $<1$ & $\begin{array}{l}\text { Use situational awareness } \\
\text { when handling glass to } \\
\text { avoid dropping or } \\
\text { bumping on counter }\end{array}$ \\
\hline 의 & $\begin{array}{l}\text { Quantitatively } \\
\text { transfer the } \\
\text { beaker } \\
\text { contents to a 1 } \\
\text { L volumetric } \\
\text { flask and } \\
\text { dilute to } \\
\text { volume with } \\
\text { DI water }\end{array}$ & $\begin{array}{l}\text { Chemical } \\
\text { splash - } \\
\text { corrosive; } \\
\text { eye } \\
\text { damage; } \\
\text { Chemical } \\
\text { spill }\end{array}$ & Low $<10$ & Same as Step 6 \\
\hline$\exists$ & $\begin{array}{l}\text { Transfer } \\
\text { prepared } \\
\text { stock solution } \\
\text { to Nalgene } \\
\text { storage bottle }\end{array}$ & $\begin{array}{l}\text { Chemical } \\
\text { splash - } \\
\text { corrosive; } \\
\text { eye } \\
\text { damage; } \\
\text { Chemical } \\
\text { spill }\end{array}$ & Low $<1$ & $\begin{array}{l}\text { Same as Step } 6 \text { PLUS } \\
\text { Check integrity of storage } \\
\text { bottle. In addition to } \\
\text { appropriate label } \\
\text { elements (chemical name, } \\
\text { date prepared, } \\
\text { concentration) the storage } \\
\text { bottle should have the } \\
\text { words, "Contains Nitric } \\
\text { Acid - do not mix with } \\
\text { organic materials" }\end{array}$ \\
\hline $\mathcal{I}$ & $\begin{array}{l}\text { Wash } \\
\text { glassware and } \\
\text { rinse with } 1+ \\
1(8 \mathrm{M}) \text { nitric } \\
\text { acid, followed } \\
\text { by ultrapure } \\
\text { DI water }\end{array}$ & $\begin{array}{l}\text { Chemical } \\
\text { splash - } \\
\text { corrosive; } \\
\text { eye } \\
\text { damage; } \\
\text { Chemical } \\
\text { spill }\end{array}$ & Low $<10$ & $\begin{array}{l}\text { Rinses can transfer from } \\
\text { piece to piece and return } \\
\text { to stock rinse solution to } \\
\text { minimize neutralization - } \\
\text { Ensure no organic } \\
\text { materials or solvents in } \\
\text { wash sink or in waste } \\
\text { containers. All nitric acid } \\
\text { waste containers should } \\
\text { plastic and be labeled as } \\
\text { such - CONTAINS } \\
\text { NITRIC ACID; DO NOT } \\
\text { ADD ORGANIC } \\
\text { MATERIALS }\end{array}$ \\
\hline
\end{tabular}




\begin{tabular}{|l|l|l|}
\hline $\begin{array}{l}\text { Return all } \\
\text { equipment to } \\
\text { storage }\end{array}$ & $\begin{array}{l}\text { Unplug electrical } \\
\text { equipment } \\
\text { Close hood sash } \\
\text { Wash hands }\end{array}$ \\
\hline $\begin{array}{l}\text { Hazards Checklist: Chemical corrosive to skin, inhalation of } \mathrm{NO}_{2} \text { (and other } \\
\text { gases evolved during this process) can cause may be fat, physical hazard of } \\
\text { oxidizing liquid, heat of reaction, possible ER action if conc. nitric acid spills. }\end{array}$ \\
\hline $\begin{array}{l}\text { Can someone be } \\
\text { exposed to } \\
\text { chemicals? Yes }\end{array}$ & $\begin{array}{l}\text { If so, what is the nature of the chemical hazard? Nitric } \\
\text { acid is a strong oxidizing acid. The concentrated form } \\
\text { will cause blistering and discoloration of skin. Inhalation } \\
\text { can cause respiratory edema. }\end{array}$ \\
SDS Reviewed? Yes
\end{tabular}




\section{Appendix B - Assessment Results}

The grading rubric shown in Table D1 was developed to evaluate ten areas of knowledge on the copper digestion JHA as well as standardize grading. During the assessment period for this assignment period, 103 assignments were evaluated. A summary of the data is shown in Figure B1.

\section{JHA Assignment Grades}

(F 2014 to S 2016)

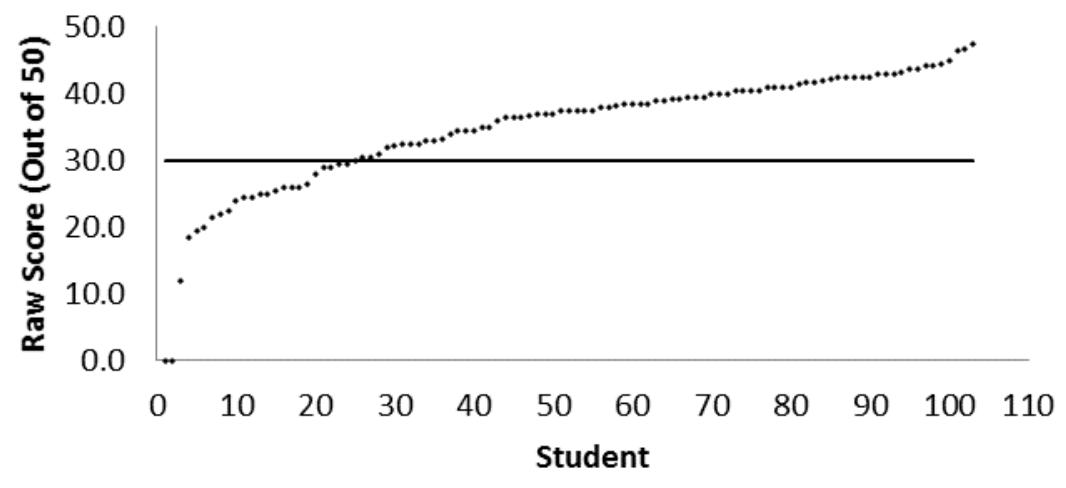

Figure B1 - Assessment Data

Although Figure B1 shows that the criterion (raw score $=30$ ) was met over the full assessment period ( $77 \%$ of the students attained a grade of 60 or better), it should be noted that there were individual semesters when the criterion was not met.

In fall of 2014, the importance of reflective work for this assignment was shown by the data. That semester, the capstone course consisted of students actively engaged in research as well as those on non-research tracks. Students submitted their JHAs for critique and then improved the tools based on that feedback. Only 14 of the 17 students resubmitted their corrected drafts for grading and therefore 3 drafts were scored without corrections. Those grades were included in the grades for the semester assessment. Including the draft grades in the data for that semester resulted in an assignment average of $62 \%$ which does not meet the $70 \%$ criterion. By not considering the 3 drafts in the data set, the criterion is met at $77 \%$ scoring 30 or better.

The importance of reflective learning was also noted in spring 2015 when the students in the non-research section were unable to have the reflective 
learning experience due to poor timing of the lecture for that section. The lecture was presented too late in the semester and we simply ran out of time to submit a JHA, allow time for comments, and score the JHAs for that section. To compensate for this, students in that section were given a document offering general flaws often seen in JHAs and suggestions for improvement. Even with this "general critique", the assessment criterion for that section (spring 2015) was not met. Only $50 \%$ of the students scored 30 or better. Compare this to the section with the research students (spring 2015) where time for reflective work was given and the criterion was met at $82.3 \%$. It is possible, however, that actively performing laboratory research contributed to the higher assignment scores for that section. 


\section{Appendix C - Information Sources}

Reliable information is vital to completing a useful risk assessment. The links listed in Table C1 will connect chemical workers to more reliable (and in most cases peer reviewed) online resources so that they may access the necessary information to understand the hazards associated with the chemicals used in their laboratory. This will enable workers to create more robust risk assessment tools. These databases and sources are offered by various agencies for free use on the Internet. Please note that some sources are intended for HAZMAT or industrial situations and the information may not be specific to use in a lab and/or quite technical. The Acronym Finder (\{ HYPERLINK "http://www.acronymfinder.com/" \}) and the Wayback Machine (\{ HYPERLINK "http://archive.org/web/web.php" \}) of archive webpages may be useful in interpreting data and retrieving broken links. 
Table C1 - Chemical Safety Information Sources List

\begin{tabular}{|c|c|c|}
\hline Site/Link & Agency or Source & Scope \& Utility \\
\hline $\begin{array}{l}\text { CAMEO Chemicals } \\
\{\text { HYPERLINK } \\
\text { "http://www.cameochem } \\
\text { icals.noaa.gov/search/si } \\
\text { mple" }\} \\
\text { (Available as a web } \\
\text { application, mobile } \\
\text { website, or as a } \\
\text { downloadable } \\
\text { application.) }\end{array}$ & $\begin{array}{l}\text { National Oceanic and } \\
\text { Atmospheric } \\
\text { Administration } \\
\text { (NOAA) }\end{array}$ & $\begin{array}{l}\text { The Computer-Aided } \\
\text { Management of Emergency } \\
\text { Operations (CAMEO) } \\
\text { chemicals software allows } \\
\text { the user to mix chemicals in } \\
\text { a virtual scenario to check } \\
\text { for reactivity between } \\
\text { chemicals and chemical } \\
\text { groups. This is helpful for } \\
\text { checking chemical } \\
\text { compatibility for storage or } \\
\text { waste containers. } \\
\text { NB: primarily intended for } \\
\text { HAZMAT }\end{array}$ \\
\hline $\begin{array}{l}\text { Chemical Safety } \\
\text { Searches } \\
\text { \{ HYPERLINK } \\
\text { "https://en.wikibooks.org } \\
\text { /wiki/Chemical_Informat } \\
\text { ion_Sources/Chemical_S } \\
\text { afety_Searches" }\}\end{array}$ & $\begin{array}{l}\text { American Chemical } \\
\text { Society (ACS) } \\
\text { Division of Chemical } \\
\text { Information (CINF) }\end{array}$ & $\begin{array}{l}\text { The American Chemical } \\
\text { Society (ACS) Division of } \\
\text { Chemical Information } \\
\text { (CINF) provides a review of } \\
\text { chemical safety information } \\
\text { sources with tips for } \\
\text { searching, includes both } \\
\text { open and subscription based } \\
\text { sources. }\end{array}$ \\
\hline $\begin{array}{l}\text { Chemical Sampling } \\
\text { Information } \\
\text { \{HYPERLINK } \\
\text { "https://www.osha.gov/d } \\
\text { ts/chemicalsampling/toc/ } \\
\text { toc_chemsamp.html" \} }\end{array}$ & $\begin{array}{l}\text { US Department of } \\
\text { Labor (DOL), } \\
\text { Occupational Safety \& } \\
\text { Health Administration } \\
\text { (OSHA) }\end{array}$ & $\begin{array}{l}\text { OSHA provides data for } \\
\text { those conducting industrial } \\
\text { hygiene investigations. Data } \\
\text { is concise with known } \\
\text { health effects (HE). }\end{array}$ \\
\hline
\end{tabular}




\begin{tabular}{|c|c|c|}
\hline Site/Link & Agency or Source & Scope \& Utility \\
\hline $\begin{array}{l}\text { ChemIDPlus Advanced } \\
\text { \{HYPERLINK } \\
\text { "http://chem.sis.nlm.nih. } \\
\text { gov/chemidplus/" }\}\end{array}$ & $\begin{array}{l}\text { US Department of } \\
\text { Health \& Human } \\
\text { Services (HHS), } \\
\text { National Institutes of } \\
\text { Health (NIH) }\end{array}$ & $\begin{array}{l}\text { The National Library of } \\
\text { Medicine (NLM) } \\
\text { Specialized Information } \\
\text { Services (SIS) provides } \\
\text { ChemIDPlus Advanced to } \\
\text { pull in chemical information } \\
\text { from a variety of agency } \\
\text { databases where the search } \\
\text { substance is listed. Very } \\
\text { powerful. Included in } \\
\text { TOXNET. }\end{array}$ \\
\hline $\begin{array}{l}\text { CHRIS } \\
\text { \{ HYPERLINK } \\
\text { "http://www.uscg.mil/hq } \\
\text { /nsfweb/foscr/ASTFOSC } \\
\text { RSeminar/References/C } \\
\text { HRISManualIntro.pdf" \} }\end{array}$ & $\begin{array}{l}\text { US Coast Guard } \\
\text { (USCG) }\end{array}$ & $\begin{array}{l}\text { The Chemical Hazards } \\
\text { Response } \\
\text { Information System } \\
\text { (CHRIS) provides useful } \\
\text { information on chemical } \\
\text { compatibility and } \\
\text { emergency response for } \\
\text { chemical incidents, } \\
\text { especially in transport. } \\
\text { NB: primarily intended for } \\
\text { HAZMAT }\end{array}$ \\
\hline $\begin{array}{l}\text { CRW } \\
\text { \{HYPERLINK } \\
\text { "http://response.restorati } \\
\text { on.noaa.gov/oil-and- } \\
\text { chemical- } \\
\text { spills/chemical- } \\
\text { spills/response- } \\
\text { tools/chemical- } \\
\text { reactivity- } \\
\text { worksheet.html" }\}\end{array}$ & $\begin{array}{l}\text { National Oceanic and } \\
\text { Atmospheric } \\
\text { Administration } \\
\text { (NOAA) }\end{array}$ & $\begin{array}{l}\text { The Chemical Reactivity } \\
\text { Worksheet (CRW) is part of } \\
\text { the Computer-Aided } \\
\text { Management of Emergency } \\
\text { Operations (CAMEO) } \\
\text { software suite as a } \\
\text { downloadable application. It } \\
\text { can be used to generate a } \\
\text { worksheet to include with a } \\
\text { risk assessment. } \\
\text { NB: primarily intended for } \\
\text { HAZMAT }\end{array}$ \\
\hline
\end{tabular}




\begin{tabular}{|c|c|c|}
\hline Site/Link & Agency or Source & Scope \& Utility \\
\hline $\begin{array}{l}\text { CSB Reports } \\
\text { \{HYPERLINK } \\
\text { "http://www.csb.gov/" \} }\end{array}$ & $\begin{array}{l}\text { US Chemical Safety } \\
\text { and Hazard } \\
\text { Investigation Board } \\
\text { (CSB) }\end{array}$ & $\begin{array}{l}\text { The US Chemical Safety } \\
\text { and Hazard Investigation } \\
\text { Board (CSB) is authorized } \\
\text { by the Clean Air Act } \\
\text { Amendments of } 1990 \\
\text { (CAA) as an independent } \\
\text { agency that investigates high } \\
\text { profile chemically related } \\
\text { accidents. Investigations } \\
\text { primarily focus on industrial } \\
\text { incidents, but provide } \\
\text { important root cause } \\
\text { information and lessons } \\
\text { learned. }\end{array}$ \\
\hline $\begin{array}{l}\text { e-CFR } \\
\text { \{ HYPERLINK } \\
\text { "http://www.ecfr.gov/cgi } \\
\text {-bin/text- } \\
\text { idx?tpl=\%2Findex.tpl" }\}\end{array}$ & $\begin{array}{l}\text { US Government } \\
\text { Printing Office } \\
\text { (GPO) }\end{array}$ & $\begin{array}{l}\text { At the Electronic Code of } \\
\text { Federal Regulations site, } \\
\text { regulatory information can } \\
\text { be located. Especially useful } \\
\text { are those in Titles } 29 \\
\text { (Labor) and } 40 \text { (Protection } \\
\text { of Environment). }\end{array}$ \\
\hline $\begin{array}{l}\text { eChemPortal } \\
\text { \{ HYPERLINK } \\
\text { "http://www.echemportal } \\
\text {.org/" \} }\end{array}$ & $\begin{array}{l}\text { Organisation for } \\
\text { Economic Co- } \\
\text { operation and } \\
\text { Development (OECD) }\end{array}$ & $\begin{array}{l}\text { eChemPortal is the OECD } \\
\text { Global Portal to Information } \\
\text { on Chemical Substances. } \\
\text { Federated searches can be } \\
\text { conducted across several } \\
\text { data sources for chemical } \\
\text { substances, properties and } \\
\text { GHS classification schema. } \\
\text { Indexed by ChemIDplus } \\
\text { Advanced. }\end{array}$ \\
\hline
\end{tabular}




\begin{tabular}{|c|c|c|}
\hline Site/Link & Agency or Source & Scope \& Utility \\
\hline $\begin{array}{l}\text { EDF Scorecards } \\
\text { \{ HYPERLINK } \\
\text { "http://scorecard.goodgui } \\
\text { de.com/index.tcl" }\} \\
\text { (add the indicated } \\
\text { information in } \\
\text { parenthesis to the above } \\
\text { address to access the } \\
\text { components) }\end{array}$ & $\begin{array}{l}\text { National } \\
\text { Environmental } \\
\text { Defense Fund (EDF) }\end{array}$ & $\begin{array}{l}\text { The EDF Scorecard program } \\
\text { is recognized by the EPA as } \\
\text { a reliable database. } \\
\text { Chemical Profiles for } \\
11,200+\text { chemicals } \\
\text { (/chemical-profiles) } \\
\text { Health Effects data } \\
\text { compiled based on the } \\
\text { specific target organ or type } \\
\text { of disease (/health-effects) } \\
\text { Regulations based chemical } \\
\text { lists (/chemical-groups) }\end{array}$ \\
\hline $\begin{array}{l}\text { Enviro-Health Links } \\
\text { for Laboratory Safety } \\
\text { \{HYPERLINK } \\
\text { "http://sis.nlm.nih.gov/en } \\
\text { viro/labsafety.html" \} }\end{array}$ & $\begin{array}{l}\text { US Department of } \\
\text { Health \& Human } \\
\text { Services (HHS), } \\
\text { National Institutes of } \\
\text { Health (NIH) }\end{array}$ & $\begin{array}{l}\text { The Specialized Information } \\
\text { Services (SIS) Enviro- } \\
\text { Health Links for Laboratory } \\
\text { Safety from the National } \\
\text { Library of Medicine (NLM) } \\
\text { lists information sources } \\
\text { relevant for laboratory scale } \\
\text { work, including } \\
\text { nonchemical hazards. }\end{array}$ \\
\hline $\begin{array}{l}\text { ERG } \\
\text { \{ HYPERLINK } \\
\text { "http://phmsa.dot.gov/ha } \\
\text { zmat/library/erg" \} }\end{array}$ & $\begin{array}{l}\text { US Department of } \\
\text { Transportation (DOT) } \\
\text { Pipeline and } \\
\text { Hazardous Materials } \\
\text { Safety Administration } \\
\text { (PHMSA) }\end{array}$ & $\begin{array}{l}\text { The DOT Emergency } \\
\text { Response Guide categorizes } \\
\text { hundreds of substances into } \\
\text { groups based on emergency } \\
\text { response protocols and } \\
\text { provides appropriate } \\
\text { response information in } \\
\text { Guides } 111 \text { through } 172 \text {. } \\
\text { NB: primarily intended for } \\
\text { HAZMAT } \\
\text { (available in mobile } \\
\text { applications) }\end{array}$ \\
\hline $\begin{array}{l}\text { GHS } \\
\text { \{ HYPERLINK } \\
\text { "http://www.unece.org/fi } \\
\text { leadmin/DAM/trans/dan } \\
\text { ger/publi/ghs/ghs_rev04/ } \\
\text { English/ST-SG-AC10- } \\
\text { 30-Rev4e.pdf" \} }\end{array}$ & $\begin{array}{l}\text { United Nations } \\
\text { Economic } \\
\text { Commission for } \\
\text { Europe (UNECE) }\end{array}$ & $\begin{array}{l}\text { Globally Harmonized } \\
\text { System of Classification and } \\
\text { Labelling of Chemicals } \\
\text { (GHS) Fourth revised } \\
\text { edition. }\end{array}$ \\
\hline
\end{tabular}




\begin{tabular}{|c|c|c|}
\hline Site/Link & Agency or Source & Scope \& Utility \\
\hline $\begin{array}{l}\text { GHS Purple Book } \\
\text { \{ HYPERLINK } \\
\text { "https://www.osha.gov/d } \\
\text { sg/hazcom/ghsguideoct0 } \\
\text { 5.pdf" \} }\end{array}$ & $\begin{array}{l}\text { US Department of } \\
\text { Labor (DOL), } \\
\text { Occupational Safety \& } \\
\text { Health Administration } \\
\text { (OSHA) }\end{array}$ & $\begin{array}{l}\text { OSHA provides a condensed } \\
\text { guide to GHS at this link. } \\
\text { (US categories) }\end{array}$ \\
\hline $\begin{array}{l}\text { HSDB } \\
\text { \{ HYPERLINK } \\
\text { "http://www.nlm.nih.gov } \\
\text { /pubs/factsheets/hsdbfs.h } \\
\text { tml" \} }\end{array}$ & $\begin{array}{l}\text { US Department of } \\
\text { Health \& Human } \\
\text { Services (HHS), } \\
\text { National Institutes of } \\
\text { Health (NIH) }\end{array}$ & $\begin{array}{l}\text { The Hazardous Substance } \\
\text { Data Bank (HSDB) from the } \\
\text { National Library of } \\
\text { Medicine (NLM) is an } \\
\text { expert reviewed database for } \\
\text { locating chemical } \\
\text { toxicology, regulatory } \\
\text { information, and physical } \\
\text { properties, etc. for c. 5,000 } \\
\text { chemicals. Included in } \\
\text { TOXNET. }\end{array}$ \\
\hline $\begin{array}{l}\text { HAZCOM } \\
\text { CFR 1910.1200 } \\
\text { \{ HYPERLINK } \\
\text { "http://www.osha.gov/pl } \\
\text { s/oshaweb/owadisp.show } \\
\text { _document?p_table=ST } \\
\text { ANDARDS\&p_id=1009 } \\
\text { 9" \} }\end{array}$ & $\begin{array}{l}\text { US Department of } \\
\text { Labor (DOL), } \\
\text { Occupational Safety \& } \\
\text { Health Administration } \\
\text { (OSHA) }\end{array}$ & $\begin{array}{l}\text { Code of Federal Regulations } \\
1910.1200 \text { Hazard } \\
\text { Communication } \\
\text { (HAZCOM) Standard } \\
\text { includes GHS definitions. }\end{array}$ \\
\hline
\end{tabular}




\begin{tabular}{|c|c|c|}
\hline Site/Link & Agency or Source & Scope \& Utility \\
\hline $\begin{array}{l}\text { INCHEM } \\
\text { \{ HYPERLINK } \\
\text { "http://www.inchem.org/ } \\
\text { " \} }\end{array}$ & $\begin{array}{l}\text { World Health } \\
\text { Organization (WHO), } \\
\text { International } \\
\text { Programme on } \\
\text { Chemical Safety } \\
\text { (IPCS) }\end{array}$ & $\begin{array}{l}\text { INCHEM links to especially } \\
\text { useful sites for risk } \\
\text { assessment purposes. The } \\
\text { site can be searched by } \\
\text { registry number (CAS) or } \\
\text { compound name. } \\
\text { Concise International } \\
\text { Chemical Assessment } \\
\text { Documents (CICADs) } \\
\text { (/pages/cicads.html) } \\
\text { Health and Safety Guides } \\
\text { (HSGs) (/pages/hsg.html) } \\
\text { International Agency for } \\
\text { Research on Cancer (IARC) } \\
\text { - Summaries and } \\
\text { Evaluations } \\
\text { (/pages/iarc.html) } \\
\text { International Chemical } \\
\text { Safety Cards (ICSCs) } \\
\text { (/pages/icsc.html) }\end{array}$ \\
\hline $\begin{array}{l}\text { Internet Resources for } \\
\text { (M)SDSs } \\
\text { "\{ HYPERLINK } \\
\text { "http://www.ilpi.com/ms } \\
\text { ds/ref/demystify.html" } \\
\text { \}" } \\
\{\text { HYPERLINK } \\
\text { "http://www.ilpi.com/ms } \\
\text { ds/" \1 "Internet" \} }\end{array}$ & $\begin{array}{l}\text { Interactive Learning } \\
\text { Paradigms, Inc. }\end{array}$ & $\begin{array}{l}\text { The Safety Emporium } \\
\text { laboratory safety supply } \\
\text { company provides an } \\
\text { overview of dozens of } \\
\text { chemical information sites } \\
\text { where (M)SDSs from } \\
\text { manufacturers, various } \\
\text { government agencies, and } \\
\text { nonprofit sources can be } \\
\text { accessed . A glossary of } \\
\text { common MSDS terms is } \\
\text { also available at. Includes a } \\
\text { glossary and the }\end{array}$ \\
\hline
\end{tabular}




\begin{tabular}{|c|c|c|}
\hline Site/Link & Agency or Source & Scope \& Utility \\
\hline $\begin{array}{l}\text { IRIS } \\
\text { \{ HYPERLINK } \\
\text { "http://www.epa.gov/iris } \\
\text { /" \} }\end{array}$ & $\begin{array}{l}\text { Environmental } \\
\text { Protection Agency } \\
\text { (EPA) }\end{array}$ & $\begin{array}{l}\text { The International Risk } \\
\text { Information System (IRIS) } \\
\text { system evaluates the health } \\
\text { risk posed by numerous } \\
\text { substances that occur in the } \\
\text { environment on the human } \\
\text { population. } \\
\text { Indexed by ChemIDplus } \\
\text { Advanced. }\end{array}$ \\
\hline $\begin{array}{l}\text { Laboratory Biosafety } \\
\text { Manual } \\
\text { \{HYPERLINK } \\
\text { "http://www.who.int/csr/ } \\
\text { resources/publications/bi } \\
\text { osafety/WHO_CDS_CS } \\
\text { R_LYO_2004_11/en/" \} }\end{array}$ & $\begin{array}{l}\text { World Health } \\
\text { Organization (WHO) }\end{array}$ & $\begin{array}{l}\text { The 3rd edition of the WHO } \\
\text { biosafety manual is very } \\
\text { complete and contains risk } \\
\text { assessment information }\end{array}$ \\
\hline $\begin{array}{l}\text { Lab Safety Information } \\
\text { Guide } \\
\text { \{ HYPERLINK } \\
\text { "http://library.stanford.e } \\
\text { du/guides/lab-safety" \} }\end{array}$ & $\begin{array}{l}\text { Stanford University } \\
\text { Library }\end{array}$ & $\begin{array}{l}\text { The Stanford Library } \\
\text { provides an extensive guide } \\
\text { of lab safety related } \\
\text { information sources, ranging } \\
\text { from substance information } \\
\text { to protocols and reaction } \\
\text { conditions; some sources } \\
\text { may not open for external } \\
\text { users. }\end{array}$ \\
\hline $\begin{array}{l}\text { Lab Standard } \\
\text { CFR 1910.1450 } \\
\text { \{HYPERLINK } \\
\text { "https://www.osha.gov/p } \\
\text { 1s/oshaweb/owadisp.sho } \\
\text { w_document?p_table=S } \\
\text { TANDARDS\&p_id=101 } \\
\text { 06" } \text { \} }\end{array}$ & $\begin{array}{l}\text { US Department of } \\
\text { Labor (DOL), } \\
\text { Occupational Safety \& } \\
\text { Health Administration } \\
\text { (OSHA) }\end{array}$ & $\begin{array}{l}\text { Code of Federal Regulations } \\
1910.1450 \text { is commonly } \\
\text { referred to as the "Lab } \\
\text { Standard". Most academic } \\
\text { research laboratories will } \\
\text { fall under this regulation in } \\
\text { OSHA states. }\end{array}$ \\
\hline $\begin{array}{l}\text { NIOSH } \\
\text { \{ HYPERLINK } \\
\text { "http://www.cdc.gov/nio } \\
\text { sh/pubs/type.html" \} }\end{array}$ & $\begin{array}{l}\text { Centers for Disease } \\
\text { Control and } \\
\text { Prevention (CDC) }\end{array}$ & $\begin{array}{l}\text { National Institute for } \\
\text { Occupational Safety and } \\
\text { Health (NIOSH) link to } \\
\text { chemical databases. }\end{array}$ \\
\hline
\end{tabular}




\begin{tabular}{|c|c|c|}
\hline Site/Link & Agency or Source & Scope \& Utility \\
\hline $\begin{array}{l}\text { NIOSH Pocket Guide } \\
\text { \{ HYPERLINK } \\
\text { "http://www.cdc.gov/nio } \\
\text { sh/npg/default.html" \} }\end{array}$ & & $\begin{array}{l}\text { The searchable NIOSH } \\
\text { Pocket Guide to Chemical } \\
\text { Hazards. } \\
\text { Indexed by ChemIDplus } \\
\text { Advanced. }\end{array}$ \\
\hline $\begin{array}{l}\text { NSCEP } \\
\text { \{ HYPERLINK } \\
\text { "http://www.epa.gov/nsc } \\
\text { ep/index.html" \} }\end{array}$ & $\begin{array}{l}\text { Environmental } \\
\text { Protection Agency } \\
\text { (EPA) }\end{array}$ & $\begin{array}{l}\text { The National Service Center } \\
\text { for Environmental } \\
\text { Publications (NSCEP) site } \\
\text { allows one to search for } \\
\text { EPA publications (print and } \\
\text { digital) by number or title. }\end{array}$ \\
\hline $\begin{array}{l}\text { PubChem LCSS } \\
\text { \{ HYPERLINK } \\
\text { "https://pubchem.ncbi.nl } \\
\text { m.nih.gov/lcss/" \} }\end{array}$ & $\begin{array}{l}\text { US Department of } \\
\text { Health \& Human } \\
\text { Services (HHS), } \\
\text { National Institutes of } \\
\text { Health (NIH) }\end{array}$ & $\begin{array}{l}\text { The PubChem Laboratory } \\
\text { Chemical Safety Summary } \\
\text { (LCSS) data view is } \\
\text { provided by the National } \\
\text { Library of Medicine (NLM) } \\
\text { National Center for } \\
\text { Biotechnology Information } \\
\text { (NCBI). The PubChem } \\
\text { database aggregates } \\
\text { chemical safety data from } \\
\text { several sources, including } \\
\text { several in this chart such as } \\
\text { GHS, HSDB, ICSCs, etc. } \\
\text { PubChem is searchable by } \\
\text { compound name, structure } \\
\text { and other common } \\
\text { identifiers. }\end{array}$ \\
\hline $\begin{array}{l}\text { RoCs } \\
\text { \{ HYPERLINK } \\
\text { "http://www.niehs.nih.go } \\
\text { v/research/atniehs/dntp/a } \\
\text { ssoc/roc/" \} }\end{array}$ & $\begin{array}{l}\text { US Department of } \\
\text { Health \& Human } \\
\text { Services (HHS), } \\
\text { National Institutes of } \\
\text { Health (NIH) }\end{array}$ & $\begin{array}{l}\text { Report on Carcinogens } \\
\text { (RoCs). National Institute of } \\
\text { Environmental Health } \\
\text { Sciences (NIEHS) National } \\
\text { Toxicology Program (NTP) } \\
\text { report (congressionally } \\
\text { mandated) on substances } \\
\text { that put humans at risk for } \\
\text { cancer. }\end{array}$ \\
\hline
\end{tabular}




\begin{tabular}{|c|c|c|}
\hline Site/Link & Agency or Source & Scope \& Utility \\
\hline $\begin{array}{l}\text { Sigma-Aldrich } \\
\text { Technical Bulletins } \\
\text { \{ HYPERLINK } \\
\text { "http://www.sigmaaldric } \\
\text { h.com/chemistry/chemic } \\
\text { al-synthesis/learning- } \\
\text { center/technical- } \\
\text { bulletins.html" \} }\end{array}$ & Sigma-Aldrich Co. & $\begin{array}{l}\text { Sigma-Aldrich offers } \\
\text { technical bulletins as } \\
\text { guidance on various topics } \\
\text { of interest for laboratory } \\
\text { workers, including handling } \\
\text { air sensitive materials, } \\
\text { conversion charts (needles, } \\
\text { pressure, etc.), cleaning } \\
\text { glassware, working in air } \\
\text { free atmospheres, and safe } \\
\text { handling of glassware. }\end{array}$ \\
\hline $\begin{array}{l}\text { TOXNET } \\
\text { \{ HYPERLINK } \\
\text { "http://toxnet.nlm.nih.go } \\
\text { v/index.html" \} }\end{array}$ & $\begin{array}{l}\text { US Department of } \\
\text { Health \& Human } \\
\text { Services (HHS), } \\
\text { National Institutes of } \\
\text { Health (NIH) }\end{array}$ & $\begin{array}{l}\text { The Toxicology Data } \\
\text { Network (TOXNET) from } \\
\text { the National Library of } \\
\text { Medicine (NLM) allows one } \\
\text { to search all the major } \\
\text { toxicology databases from } \\
\text { one site, including HSDB } \\
\text { and ChemIDPlus Advanced. }\end{array}$ \\
\hline $\begin{array}{l}\text { WISER } \\
\text { \{ HYPERLINK } \\
\text { "http://webwiser.nlm.nih } \\
\text {.gov/getHomeData.do;js } \\
\text { essionid=D6EFB295EB } \\
\text { 6E2E836A6A876DE4F } \\
\text { BCD4B" \} } \\
\text { WebWISER } \\
\text { Download: } \\
\text { \{ HYPERLINK } \\
\text { "https://outlook.office36 } \\
\text { 5.com/owa/redir.aspx?R } \\
\text { EF=3qAkhvq- } \\
\text { JeuEfxFLnp3jF11WKkR } \\
\text { 3WTe4CplrvDmyl2OJ4 } \\
\text { AeZ4fnSCAFodHRwOi } \\
\text { 8vd2lzZXIubmxtLm5pa } \\
\text { C5nb3Yv" \t "_blank" \} }\end{array}$ & $\begin{array}{l}\text { US Department of } \\
\text { Health \& Human } \\
\text { Services (HHS), } \\
\text { National Institutes of } \\
\text { Health (NIH) }\end{array}$ & $\begin{array}{l}\text { The National Library of } \\
\text { Medicine (NLM) provides } \\
\text { the Wireless Information } \\
\text { System for Emergency } \\
\text { Responders (WISER) "to } \\
\text { assist emergency responders } \\
\text { in hazardous material } \\
\text { incidents. WISER provides } \\
\text { a wide range of information } \\
\text { on hazardous substances, } \\
\text { including substance } \\
\text { identification support, } \\
\text { physical characteristics, } \\
\text { human health information, } \\
\text { and containment and } \\
\text { suppression advice." } \\
\text { Indexed by ChemIDplus } \\
\text { Advanced. }\end{array}$ \\
\hline
\end{tabular}




\section{Appendix D - Grading Rubric for Job Hazard Analysis (JHA) for Copper Digestion}

Assignment: Prepare one liter of a $1000 \mathrm{ppm}$ stock solution of copper(II) ions from copper solid (CAS 7440-50-8) and concentrated nitric acid (CAS 7697-37-2) for AAS standards.

Students construct a JHA in the instructor provided template (see completed example in Appendix A). All references to additional hazard information, SOPs, risk matrices or other supporting information to control hazards should also be included in the template as links or as attachments. The student prepared JHAs are graded on ten (10) knowledge/information categories shown in Table D1.

Table D1 - Grade Sheet for Copper Digestion

\begin{tabular}{|l|l|l|}
\hline \multicolumn{2}{|l|}{$\begin{array}{l}\text { Grading Sheet for Copper Digestion JHA } \\
30 \text { is Competent }\end{array}$} & Points \\
\hline \multicolumn{2}{|l|}{ Header \& Footer Information } & \\
\hline 1 & Equipment \& Chemicals Required & \\
\hline 3 & $\begin{array}{l}\text { Adequate Number of Steps Provided to Accurately } \\
\text { Describe the Task }\end{array}$ & \\
\hline 4 & Major Steps Identified & \\
\hline 5 & PPE Type \& Use Well Defined & \\
\hline 6 & Hazards Checklist & \\
\hline 7 & Significant Hazards Identified in the Given Steps & \\
\hline 8 & Method of Risk Determination Stated & \\
\hline 9 & $\begin{array}{l}\text { Risk Description is Appropriately Assessed for Step } \\
\text { (not too high or too low) }\end{array}$ & \\
\hline 10 & Controls Sufficient to Lower Risk & \\
\hline
\end{tabular}

Points are assigned as follows:

EXCELLENT (5 pts max)

COMPETENT (3 pts max)

NEEDS IMPROVEMENT [Needs Imp.] (1 pts max)

Example criteria to assign points in each category are shown below. 


\section{Required General Information}

1. Header \& Footer Information

EXCELLENT The JHA lists the job location, date, and person preparing the tool. Signed if hard copy.

COMPETENT One of the required items is missing.

NEEDS IMP. More than one of the required items is missing.

\section{Equipment \& Chemicals Required}

EXCELLENT Engineering Controls: chemical fume hood, eyewash/shower unit; spill tray Equipment: metal free volumetric and graduated glassware, metal free Nalgene storage bottle, wash bottle, analytical balance, stirring hotplate w/magnet, Chemicals: copper metal $(5 \mathrm{~N})$, metal free nitric acid, ultrapure DI water, $P P E$ : chemical splash goggles, chemical resistant gloves, lab coat or apron. (Optional: face shield) $E R$ : spill equipment

COMPETENT Engineering Controls: Chemical fume hood, eyewash/shower unit

Equipment: volumetric and graduated glassware, storage bottle, wash bottle, balance, stirring hotplate w/magnet, copper metal (form not specified), nitric acid, DI water

$P P E$ : chemical splash goggles, chemical resistant gloves, lab coat or apron

NEEDS IMP. Engineering Controls: Chemical fume hood Equipment: volumetric glassware, stirring hotplate, nitric acid, water

$P P E$ : goggles and gloves

\section{$\underline{\text { Steps }}$}

3. Adequate Number of Steps Provided to Accurately Describe the Task

EXCELLENT $8-12$ unique, meaningful steps

COMPETENT $5-7$ unique steps

NEEDS IMP. $\quad<5$ steps

4. Major Steps Identified

EXCELLENT Obtain copper

Weigh solid copper $(\mathrm{Cu})$ wire on analytical balance 
Return copper

Transfer $\mathrm{Cu}$ wire to a $250 \mathrm{~mL}$ beaker

Place beaker containing $\mathrm{Cu}$ on stirring hotplate in

hood, add magnet

Remove stock bottle of concentrated nitric acid from

storage

Transfer $\sim 50 \mathrm{~mL}$ of con nitric to $250 \mathrm{~mL}$ beaker

Return stock bottle of concentrated nitric acid to

storage

Add $30 \mathrm{~mL}$ of concentrated nitric acid $\left(16 \mathrm{M} \mathrm{HNO}_{3}\right)$

- beaker graduations offer sufficient accuracy. Stir

slowly to displace nitrogen dioxide $\left(\mathrm{NO}_{2}\right)$ a toxic

brown gas. Cover with watch glass

Once gas production has stopped, check for reaction

completion - Ensure that $\mathrm{Cu}$ wire has completely

dissolved.

Add $300 \mathrm{~mL}$ of DI water to $1 \mathrm{~L}$ volumetric flask

Quantitatively transfer the beaker contents to a $1 \mathrm{~L}$

volumetric flask and dilute to volume with DI water

Transfer prepared stock solution to a labeled Nalgene storage bottle

Wash glassware and rinse with $1+1(8 \mathrm{M})$ nitric acid, followed by ultrapure DI water. Wash hands

COMPETENT Weigh solid copper

Transfer $\mathrm{Cu}$ wire to a beaker

Place beaker containing $\mathrm{Cu}$ on stirring hotplate in

hood

Obtain acid

Add of concentrated nitric acid $\left(16 \mathrm{M} \mathrm{HNO}_{3}\right)$ Stir

slowly to dissolve

Once gas production has stopped, check for reaction

completion

Transfer the beaker contents to a $1 \mathrm{~L}$ volumetric flask and dilute to volume with DI water

Clean up

NEEDS IMP. Weigh solid copper and transfer to beaker

Place beaker in hood

Add of concentrated nitric acid $\left(16 \mathrm{M} \mathrm{HNO}_{3}\right)$ Stir

slowly to dissolve

Dilute to volume with DI water 


\section{Personal Protective Equipment (PPE)}

5. PPE Type \& Use Well Defined

EXCELLENT Chemical splash goggles, gloves of best material documented), lab coat or apron

COMPETENT Goggles, gloves (material not documented), and lab coat

NEEDS IMP. Eye protection and gloves

\section{Hazards}

6. Hazards Checklist

EXCELLENT Chemical corrosive to skin, inhalation (toxic gas); Physical hazard of oxidizing liquid, heat of reaction; Possible emergency response action required if conc. nitric acid spills

COMPETENT Mention of at least one health hazard (corrosive to skin or lungs) At least one physical hazard (heat of reaction, oxidizing acid).

NEEDS IMP. Mention of only health hazards.

7. Significant Hazards Identified in the Given Steps

EXCELLENT Dermal contact with metal

Chemical splash - corrosion to eyes, skin, and lungs

Toxic gas

Chemical spill possible

Oxidation hazard (incompatible with organic

materials)

Supporting material supplied with JHA (SDS, SOP,

etc.)

Electrical

Cuts

COMPETENT Chemical splash/corrosive material

Toxic gas

Chemical spill possible

Supporting material mentioned (e.g. See SDS for nitric acid)

Cuts

NEEDS IMP. Chemical splash/corrosive material

Cuts

No supporting material 
$\underline{\text { Risk }}$

8. Method of Risk Determination Stated

EXCELLENT Method given and risk stated quantitatively \& qualitatively

COMPETENT Method given and risk stated qualitatively or quantitatively

NEEDS IMP. No method given - stated qualitatively

9. Risk Description is Appropriately Assessed for Step (not too high or too low)

EXCELLENT Risk assignments are proportional to actual risk

All steps of high risk are noted as high risk

Low risk steps are recognized

COMPETENT Most high risk steps are identified

Most low risk steps are recognized

NEEDS IMP. High risk steps are not recognized

Low risk steps are disproportionally assigned high

risk values

\section{$\underline{\text { Risk Control }}$}

10. Controls Sufficient to Lower Risk

EXCELLENT Exposure Controls (PPE): Worker will don chemical splash goggles, nitrile gloves add polyethylene gloves and a lab coat or apron. Add face shield if close inspection of reaction beaker is required - do not hold over body

Engineering Controls: WORK IN FUME HOOD lower sash; set up at least 6" inside, use spill tray Administrative Include and review SDS as a control in this JHA. Signed JHA. Information documented. ER Controls: Spill kit w/ non organic neutralizing material, review ER procedures and spill kit use Reactivity: Nitric acid is very reactive. Do not underestimate this hazard. Ensure no organic materials or solvents in wash sink or hood. Environmental/Waste: In addition to appropriate label elements (chemical name, date prepared, concentration) the storage bottle should have the words, "Contains Nitric Acid - do not mix with organic waste", Rinses can transfer from piece to piece and return to stock rinse solution to minimize neutralization 
COMPETENT Exposure Controls (PPE): Worker wears goggles, gloves, and lab coat or apron.

Engineering Controls: WORK IN FUME HOOD

ER Controls: Spill kit w/ neutralizing material.

Reactivity: Ensure no organic materials or solvents in wash sink.

Environmental/Waste: Collect waste and label.

NEEDS IMP. Exposure Controls (PPE): Worker wears goggles, gloves, and lab coat or apron.

Engineering Controls:_WORK IN FUME HOOD

ER Controls: Spill kit w/ neutralizing material 


\section{References}

(1) Trager, R. UCLA chemist to stand trial for safety violations linked to Sheri Sangji death. Chemistry World, May 1, 2013. \{ HYPERLINK "http://www.rsc.org/chemistryworld/2013/05/ucla-chemist-trial-safetyviolations-linked-sheri-sangji-death" \} (accessed Nov. 20, 2015).

(2) Lippincolt, W.T. Safety and Health in Academic Laboratories. J. Chem. Educ. 1977, 54, $719 . \quad$ \{ HYPERLINK "http://pubs.acs.org/doi/abs/10.1021/ed054p719" \} (accessed June 8, 2016).

(3) Currano, J. N. Teaching Chemical Information for the Future: The More Things Change, the More They Stay the Same. In The Future of the History of Chemical Information; McEwen, L. R.; Buntrock, B. E., Eds.; ACS Symposium Series; American Chemical Society: Washington, DC, 2014; Vol. 1164, pp 169-196. Chapter DOI: 10.1021/bk-2014-1164.ch01.

(4) Gallion, L. A., Samide, M. J., \& Wilson, A. M. Demonstrating the importance of cleanliness and safety in an undergraduate teaching laboratory. J. Chem. Health Saf., 2015, 22, 28-31. \{ HYPERLINK "http://www.sciencedirect.com/science/article/pii/S1871553215000031" \} (accessed June 8, 2016).

(5) Kemsley, J. Dow Chemical Teams Up With Universities On Laboratory Safety. Chem. Eng. News. 2012, 90, 21-23. http://cen.acs.org/articles/90/i44/Dow-Chemical-Teams-UniversitiesLaboratory.html (accessed Nov. 20 2015).

(6) Livingston, H. K. Safety Considerations in Research Proposals. J. Chem. Educ. 1964, 41, A785-A789.

(7) Job Hazard Analysis; OSHA 3071; revised 2002. United States Department of Labor, Occupational Safety and Health Administration. https://www.osha.gov/Publications/osha3071.html (accessed Nov. 20, 2015).

(8) American Chemical Society, Committee on Professional Training. Undergraduate Professional Education in Chemistry: ACS Guidelines and Evaluation Procedures for Bachelor's Degree Programs; American Chemical Society: Washington, DC, 2015. http://www.acs.org/content/dam/acsorg/about/governance/committees/traini ng/2015-acs-guidelines-for-bachelors-degree-programs.pdf (accessed Nov. 20, 2015).

(9) Blanchard, P. N.; Thacker, J. W. Effective Training Systems, Strategies, and Practices, Custom Edition; Pearson Custom Publishing, Pearson: New York, NY, 2010; Chapters 1-5.

(10) Sigmann, S. B. Using traditional safety rules to teach more advanced concepts in chemical hygiene. CHAS 17, presented at the $249^{\text {th }}$ American 
Chemical Society National Meeting \& Exposition, Denver, CO, March $24^{\text {th }}$, 2015.

(11) American Chemical Society, Committee on Chemical Safety, Hazard Identification and Evaluation Task Force. Identifying and Evaluating Hazards in Research Laboratories. Washington, DC, 2015. \{ HYPERLINK "http://www.acs.org/content/dam/acsorg/about/governance/committees/che micalsafety/publications/identifying-and-evaluating-hazards-in-researchlaboratories.pdf" \} (accessed Nov. 20, 2015).

(12) American Chemical Society, Committee on Professional Training. ACS Guidelines Supplement: Chemical Information Skills; American Chemical Society: Washington, DC, 2015. \{ HYPERLINK "http://www.acs.org/content/dam/acsorg/about/governance/committees/train ing/acsapproved/degreeprogram/chemical-information-skills.pdf" (accessed Nov. 20, 2015).

(13) Alaimo, P.J.; Langenhan, J.M.; Tanner, M.; Ferrenberg, S.M. Safety teams: An approach to engage students in laboratory safety. J. Chem. Educ. 2010, 87 , 856-861. \{ HYPERLINK "http://pubs.acs.org/doi/abs/10.1021/ed100207d" \} (accessed June 8, 2016).

(14) Globally Harmonized System of Classification and Labelling of Chemicals. United Nations, Committee of Experts on the Transport of Dangerous Goods and on the Globally Harmonized System of Classification and Labelling of Chemicals (UNCETDG/GHS). New York and Geneva, 2003. \{ HYPERLINK

"http://www.unece.org/trans/danger/publi/ghs/ghs_welcome_e.html" \} (accessed Nov. 20, 2015).

(15) National Institutes of Health, National Library of Medicine, Specialized Information Services. ChemIDPlus Advanced, Homepage. \{ HYPERLINK "http://chem.sis.nlm.nih.gov/chemidplus/" \} (accessed Nov. 20, 2015).

(16) Prudent Practices in the Laboratory: Handling and Management of Chemical Hazards, Updated Version; National Research Council. The National Academies Press: Washington, DC, 2011. \{ HYPERLINK "http://www.nap.edu/catalog/12654/prudent-practices-in-the-laboratoryhandling-and-management-of-chemical" \} (accessed Nov. 20, 2015).

(17) Kim, S.; McEwen, L.; Stuart, R.; Thiessen, P.; Gindulyte, A.; Zhang, J.; Bolton, E.; Bryant, S. PubChem Laboratory Chemical Safety Summary. American Chemical Society, Division of Chemical Education, Committee on Computers in Chemical Education, ConfChem Newsletter Fall 2015, November 5, 2015, \{ HYPERLINK "http://confchem.ccce.divched.org/2015FallCCCENLP3" \}\{ HYPERLINK "http://confchem.ccce.divched.org/2015FallCCCENLP3" \}\{ HYPERLINK "http://confchem.ccce.divched.org/2015FallCCCENLP3" \} (accessed Nov. 20, 2015). 
(18) National Institutes of Health, National Library of Medicine, Specialized Information Services. Enviro-Health Links for Laboratory Safety, Homepage. \{ HYPERLINK "http://sis.nlm.nih.gov/enviro/labsafety.html" \} (accessed Nov. 20, 2015).

(19) Stony Brook University, Environmental Health and Safety. Hazard \& Risk Evaluation Matrix, EHSDO368 (rev. 02/13). \{ HYPERLINK "http://www.asa.stonybrook.edu/asa/asaforms/EHSD0368/\$FILE/EHSD036 8.pdf" \} (accessed Nov. 20, 2015).

(20) American Library Association, Association of College and Research Libraries. Information Literacy Competency Standards for Higher Education; American Library Association: Chicago, IL, 2000. \{ HYPERLINK

"http://www.ala.org/acrl/sites/ala.org.acrl/files/content/standards/standards. pdf" \} (accessed Nov. 20, 2015).

(21) Stuart, R. B.; McEwen, L. R. The Safety "Use Case": Co-Developing Chemical Information Management and Laboratory Safety Skills. J. Chem. Educ. 2015, 93, 516-526, \{ HYPERLINK "http://pubs.acs.org/doi/abs/10.1021/acs.jchemed.5b00511" \} (accessed June 8, 2016).

(22) American Library Association, Association of College and Research Libraries. Framework for Information Literacy for Higher Education; American Library Association: Chicago, IL, 2015. \{ HYPERLINK "http://www.ala.org/acrl/standards/ilframework" \} (accessed Nov. 20, 2015).

(23) Institute of Museum and Library Services. Rubric Assessment of Information Literacy Skills. http://railsontrack.info (accessed Nov. 20, 2015).

(24) Special Libraries Association, Chemistry Division and American Chemical Society, Division of Chemical Information. Information Competencies for Chemistry Undergraduates: The Elements of Information Literacy. 2nd ed. 2011. \{ HYPERLINK "http://chemistry.sla.org/wpcontent/uploads/cheminfolit.pdf" \} (accessed Nov. 20, 2015).

(25) Glenn, D. D. Job Safety Analysis: It's Role Today. Professional Safety. 2011, 56, 48-57.

(26) Ramey, M. A.R. CHE 4000 Chemistry Seminar, Syllabus Section 101. Smith Department of Chemistry, Appalachian State University: Boone, NC, 2016.

(27)Hazardous Substances Risk Assessment Form, Other Risk Assessment Resources. Safetyrisk.net. \{ HYPERLINK "http://www.safetyrisk.net/riskassessment-form-templates/" \} (accessed Nov. 20, 2015).

(28) Preston, L. Personal communication, September 14, 2015.

(29) Hill, R. H.; Finster, D. C. Laboratory Safety for Chemistry Students; Wiley: Hoboken, NJ, 2010. 